Purdue University

Purdue e-Pubs

$10-2018$

\title{
Chemical Stability and Reaction Kinetics of Two Thiamine Salts (Thiamine Mononitrate and Thiamine Chloride Hydrochloride) in Solution
}

\author{
Lisa J. Mauer \\ Purdue University, mauer@purdue.edu \\ Adrienne L. Voelker \\ Purdue University \\ Jenna Miller \\ Purdue University \\ Cordelia Running \\ Purdue University, crunning@purdue.edu \\ Lynne S. Taylor \\ Purdue University
}

Follow this and additional works at: https://docs.lib.purdue.edu/foodscipubs

\section{Recommended Citation}

Mauer, Lisa J.; Voelker, Adrienne L.; Miller, Jenna; Running, Cordelia; and Taylor, Lynne S., "Chemical Stability and Reaction Kinetics of Two Thiamine Salts (Thiamine Mononitrate and Thiamine Chloride Hydrochloride) in Solution" (2018). Department of Food Science Faculty Publications. Paper 15. https://docs.lib.purdue.edu/foodscipubs/15 
This is the author copy of an accepted manuscript, posted to the Purdue University Repository after an embargo period as permitted by the publisher.

The published copy can be found at:

Chemical stability and reaction kinetics of two thiamine salts (thiamine mononitrate and thiamine chloride hydrochloride) in solution

AL Voelker, J Miller, CA Running, LS Taylor, LJ Mauer

Food research international 112, 443-456

https://doi.org/10.1016/j.foodres.2018.06.056 


\title{
Chemical stability and reaction kinetics of two thiamine salts (thiamine mononitrate and thiamine chloride hydrochloride) in solution
}

\author{
Adrienne Voelker ${ }^{1}$, Jenna Miller ${ }^{1}$, Cordelia A. Running² ${ }^{2}$ Lynne S. Taylor ${ }^{3}$, Lisa J. Mauer ${ }^{*}$ \\ ${ }^{1}$ Department of Food Science, Purdue University, 745 Agriculture Mall Drive, West Lafayette, \\ Indiana 47907, United States \\ Lisa J. Mauer: mauer@purdue.edu \\ Adrienne Voelker: avoelke@purdue.edu \\ 2 Department of Nutrition Science, Purdue University, 700 West State Street, West Lafayette, \\ Indiana 47907, United States \\ Cordelia A. Running: crunning@purdue.edu \\ ${ }^{3}$ Department of Industrial and Physical Pharmacy, Purdue University, 575 Stadium Mall Drive, \\ West Lafayette, Indiana 47907, United States \\ Lynne S. Taylor: lstaylor@purdue.edu
}

*Corresponding author: Lisa J. Mauer; Department of Food Science, Purdue University; 745 Agriculture Mall Drive, West Lafayette, Indiana 47907, United States; Email:

mauer@purdue.edu; Phone: 765-494-9111

Declarations of interests: none 


\section{Abstract}

Two types of thiamine (vitamin $\mathrm{B}_{1}$ ) salts, thiamine mononitrate (TMN) and thiamine

5 chloride hydrochloride ( $\mathrm{TClHCl}$ ), are used to enrich and fortify food products. Both of these

6 thiamine salt forms are sensitive to heat, alkali, oxygen, and radiation, but differences in stability

7 between them have been noted. It was hypothesized that stability differences between the two

8 thiamine salts could be explained by differences in solubility, solution $\mathrm{pH}$, and activation

9 energies for degradation. This study directly compared the stabilities of TMN and TClHCl in

10 solution over time by documenting the impact of concentration and storage temperature on

11 thiamine degradation and calculating reaction kinetics. Solutions were prepared containing five

12 concentrations of each thiamine salt $(1,5,10,20$, and $27 \mathrm{mg} / \mathrm{mL})$, and three additional

13 concentrations of TClHCl: 100, 300, and $500 \mathrm{mg} / \mathrm{mL}$. Samples were stored at 25, 40, 60, 70, and

$1480^{\circ} \mathrm{C}$ for up to 6 months. Degradation was quantified over time by high-performance liquid

15 chromatography, and percent thiamine remaining was used to calculate reaction kinetics. First-

16 order reaction kinetics were found for both TMN and TClHCl. TMN degraded significantly

17 faster than $\mathrm{TClHCl}$ at all concentrations and temperatures. For example, in $27 \mathrm{mg} / \mathrm{mL}$ solutions

18 after 5 days at $80^{\circ} \mathrm{C}$, only $32 \%$ of TMN remained compared to $94 \%$ of TClHCl. Activation

19 energies and solution $\mathrm{pHs}$ were 21-25 kcal/mol and $\mathrm{pH}$ 5.36-6.96 for TMN and 21-32 kcal/mol

20 and $\mathrm{pH}$ 1.12-3.59 for TClHCl. TClHCl degradation products had much greater sensory

21 contributions than TMN degradation products, including intense color change and potent aromas,

22 even with considerably less measured vitamin loss. Different peak patterns were present in

23 HPLC chromatograms between TMN and TClHCl, indicating different degradation pathways

24 and products. The stability of essential vitamins in foods is important, even more so when

25 degradation contributes to sensory changes, and this study provides a direct comparison of the 
26 stability of the two thiamine salts used to fortify foods in environments relevant to the processing

27 and shelf-life of many foods.

28

\section{Key Words}

30 Thiamine, vitamin $\mathrm{B}_{1}$, chemical stability, degradation, reaction kinetics, activation energy, $\mathrm{pH}$, 31 sensory, thiamine mononitrate, thiamine chloride hydrochloride 
33 Vitamin $\mathrm{B}_{1}$, also known as thiamine (Figure 1), is an essential micronutrient in the

34 human diet that is found both naturally and as a fortification supplement in many foods.

35 Thiamine acts as a coenzyme for metabolism of carbohydrates and branched-chain amino acids

36 and has roles in digestion, the nervous system, and muscle contraction (Institute of Medicine,

37 1998). Thiamine deficiency persists in both developing and developed countries. In developing

38 countries, a lack of nutritious food or nutritional variety, which may occur when unfortified

39 grains such as polished rice are the main dietary component, are the main contributors to

40 thiamine deficiency, which is found in up to 25\% of the population (Ball, 2006; Prinzo, 1999).

41 In developed countries, where fortification efforts have reduced overall rates of thiamine

42 deficiency to near $10 \%$, deficiency is more likely found in alcoholics, people on strict weight

43 loss diets, and people avoiding consumption of fortified grain products, including those with

44 Celiac’s disease (Ball, 2006; Shepherd \& Gibson, 2013). Thiamine deficiency can cause both

45 minor symptoms, such as fatigue, insomnia, irritability, and other neurological indicators, as well

46 as severe diseases resulting from prolonged deficiency, e.g., Beriberi and Wernicke-Korsakoff

47 syndrome (Spitzer \& Schweigert, 2007). Thiamine stores in the body are very small and last

48 only weeks, which contributes to the concern of deficiency (Baumgartner, Henderson, Fox, \&

49 Gondi, 1997). The Recommended Dietary Allowance (RDA) and Daily Value (DV) for

50 thiamine in the U.S. are both $1.2 \mathrm{mg} /$ day(Institute of Medicine, 1998; U.S. Food \& Drug

51 Administration, 2018). To combat the likelihood of deficiency, thiamine salts are often used to

52 enrich and fortify many food and beverage products.

53 Thiamine is found naturally in foods, such as meats, yeast, whole grains, nuts, pulses, and

54 legumes, in a phosphorylated form, most commonly thiamine triphosphate (Gregory III, 2008). 
55 Additionally, two salt forms are used as food additives: thiamine mononitrate* (TMN) and

56 thiamine chloride hydrochloride (TClHCl) (Figure 1). TMN is a mono-salt, with only one nitrate

57 anion present, and $\mathrm{TClHCl}$ is a di-salt with two chlorides present. $\mathrm{TClHCl}$ is often

58 interchangeably called 'thiamine hydrochloride' (Ash, 2008); however, it is important to note

59 that the molecular formula contains two chlorides $\left(\mathrm{C}_{12} \mathrm{H}_{17} \mathrm{ClN}_{4} \mathrm{OS} \bullet \mathrm{HCl}\right)$, as shown in Figure 1.

60 While thiamine has two $\mathrm{pK}_{\mathrm{a}}\left(\mathrm{pK}_{\mathrm{a} 1}=4.8\right.$ for the pyrimidine $\mathrm{N} 1$ and $\mathrm{pK}_{\mathrm{a}} 2=9.2$ for the thiazole

61 quarternary nitrogen (Edwards et al., 2017)), $\mathrm{pK}_{\mathrm{a} 1}$ is the only relevant $\mathrm{pK}_{\mathrm{a}}$ for the majority of

62 food products. Solid state properties of TMN and TClHCl differ widely from one another (Table

63 1). TMN is often used in dry food products due to its low hygroscopicity, and TClHCl is often

64 used in liquid or beverage products due to its high solubility (Labuza \& Kamman, 1982). The

65 higher solubility of TClHCl compared to TMN is due to the higher free energy of the TClHCl

66 crystalline salt form (Atkins \& de Paula, 2006). The two salt forms also have substantial

67 stability differences that have been explained by different activation energies, reported as 22.4

$68 \mathrm{kcal} / \mathrm{mol}$ for TClHCl and $26.3 \mathrm{kcal} / \mathrm{mol}$ for TMN in solid state systems, with $E_{a}$ decreasing as

69 water activity (a $\mathrm{a}_{\mathrm{w}}$ ) increased (Labuza \& Kamman, 1982).

70 Thiamine is one of the most heat sensitive vitamins (Feliciotti \& Esselen, 1957). It is

71 often destroyed during thermal processing and, in addition to heat, is also sensitive to alkali,

72 oxygen, radiation, sulfites, and the food matrix (Gregory III, 2008; Spitzer \& Schweigert, 2007).

73 Bis(2-methyl-3-furyl) disulfide, one possible degradation product of thiamine, delivers one of the

74 lowest reported odor threshold values of any organic compound in water, at 0.02 parts per trillion

\footnotetext{
* Abbreviations: TMN, thiamine mononitrate; TClHCl, thiamine chloride hydrochloride; HPLC, high performance liquid chromatography; Ea, activation energy, kobs, reaction rate constant; $a_{w}$, water activity; t90, time when $90 \%$ of the initial concentration remains
} 
75 (Buttery, Haddon, Seifert, \& Turnbaugh, 1984). The presence of water has been shown to

76 negatively impact the stability of thiamine in the solid state, with degradation rates increasing as

77 relative humidity or $\mathrm{a}_{\mathrm{w}}$ increase, especially when the deliquescence point is exceeded (Dennison,

78 Kirk, Bach, Kokoczka, \& Heldman, 1977; Hiatt, Ferruzzi, Taylor, \& Mauer, 2008; Labuza \&

79 Tannenbaum, 1972). Many studies have also monitored the short-term stability of thiamine,

80 primarily in its chloride hydrochloride form, in solution at very high temperatures, specifically as

81 a function of pH (Dwivedi \& Arnold, 1972; Farrer \& Morrison, 1949; Feliciotti \& Esselen, 1957;

82 Williams \& Ruehle, 1935). However, long term observations are lacking regarding the stability

83 of thiamine in solution at temperatures to which foods are likely exposed, and few studies have

84 directly compared the stability of TClHCl and TMN.

85 The objectives of this study were to: 1) investigate the impacts of concentration and

86 storage temperature on the stability of thiamine in solutions prepared from TClHCl or TMN, 2)

87 calculate activation energies of thiamine degradation using the temperature-dependent stability

88 data collected from TClHCl and TMN solutions, 3) directly compare thiamine stability over time

89 in solutions prepared from TMN and TClHCl, and 4) document if a difference in sensory impact

90 exists in thiamine degraded in solutions prepared from $\mathrm{TClHCl}$ and TMN. The results of this

91 study will provide a practical approach for understanding the delivery of thiamine salts in

92 beverages and products containing varying amounts of water in which higher concentrations of

93 thiamine could be found.

94

95 2. Materials and Methods

96 2.1 Materials: 
Two thiamine salt forms were studied: thiamine mononitrate (TMN), $\mathrm{C}_{12} \mathrm{H}_{17} \mathrm{~N}_{4} \mathrm{OS} \bullet$

$98 \mathrm{NO}_{3}$, obtained from Spectrum Chemical Mfg. Corp. (New Brunswick, NJ), and thiamine

99 chloride hydrochloride (TClHCl), $\mathrm{C}_{12} \mathrm{H}_{17} \mathrm{ClN}_{4} \mathrm{OS} \bullet \mathrm{HCl}$, obtained from Fisher Scientific (Fair

100 Lawn, NJ). For use in high performance liquid chromatography (HPLC), HPLC grade

101 acetonitrile was obtained from Fisher Scientific and HPLC grade trifluoroacetic acid was

102 obtained from Sigma-Aldrich Inc. (St. Louis, MO). Water used in all experiments was deionized

103 and purified using a Barnstead E-Pure ultrapure water purification system with a resistivity at

$10425^{\circ} \mathrm{C}$ greater than $17.5 \mathrm{M} \Omega \cdot \mathrm{cm}$ (ThermoScientific, Waltham, MA).

105

106 2.2 Solubility Measurement:

107 The maximum solubility of each vitamin salt form in water at ambient temperature was

108 determined, using a method adapted from Young (Young, 1957), to later use as a basis for

109 preparing different solution concentrations of each sample. Beginning with 125 mg TMN or 50

$110 \mathrm{mg}$ TClHCl and $50 \mathrm{~mL}$ of water for each trial (based on reported solubility values), a mass

111 balance was used to determine the saturation point by alternating additions of water (dropwise)

112 and vitamin solid (1 mg). Saturation point was characterized by the inability of additional

113 crystalline vitamin to be dissolved in solution. Volume was measured in a volumetric flask to

114 quantify solubility in $\mathrm{mg} / \mathrm{mL}$ of total solution.

115

\section{2.3 Sample Preparation:}

117 To understand the impact of thiamine concentration in solution on vitamin stability,

118 series of TMN and TClHCl solutions were prepared containing 5 thiamine concentrations: 1, 5,

11910,20 , and $27 \mathrm{mg} / \mathrm{mL}$ (the latter is just under the maximum solubility of TMN). Solutions 
120 containing higher concentrations of $\mathrm{TClHCl}$ were also prepared $(100,300$, and $500 \mathrm{mg} / \mathrm{mL})$ to

121 investigate behaviors in solutions nearing the saturation point of $\mathrm{TClHCl}$. The range and number

122 of concentrations chosen provided data for calculating reaction kinetics. The samples were

123 prepared in terms of mass concentration rather than molar concentration, and although the two

124 salt forms have slightly different molecular weights (Table 1), all calculations were done using

125 percent remaining values, which account for this small discrepancy. Solutions (10 mL)

126 containing each vitamin concentration were prepared in triplicate in $20 \mathrm{~mL}$ amber glass

127 scintillation vials with PE cone-lined phenolic caps that were sealed with duct tape to prevent

128 evaporation. Headspace in these vials was not modified prior to storage.

\section{$130 \quad 2.4$ Sample Storage:}

131 To monitor the effect of temperature on thiamine stability, solutions were stored at 5

132 temperatures: $25^{\circ} \mathrm{C}, 40^{\circ} \mathrm{C}, 60^{\circ} \mathrm{C}, 70^{\circ} \mathrm{C}$, and $80^{\circ} \mathrm{C}$. These temperatures were chosen to provide a

133 large range of temperatures for calculating temperature-dependent reaction kinetics. The $25^{\circ} \mathrm{C}$

134 condition was used as an ambient temperature control and was maintained within $\pm 1^{\circ} \mathrm{C}$ using a

135 temperature-controlled room (Commercial Fixture Company Inc., Indianapolis, IN). The $40^{\circ} \mathrm{C}$,

$13660^{\circ} \mathrm{C}$, and $70^{\circ} \mathrm{C}$ temperatures were maintained using Forma Scientific water-jacketed incubators

137 (Thermo Fisher Scientific Inc., Marietta, $\mathrm{OH}$ ). The $80^{\circ} \mathrm{C}$ temperature was maintained using a

138 digital heatblock (VWR International, Radnor, PA). To monitor storage conditions, temperature

139 was confirmed by liquid-in-glass partial immersion thermometers. Solutions were stored in

140 controlled temperature environments for up to 6 months, depending on temperature and vitamin

141 form, and were analyzed for percent vitamin remaining at a minimum of 5 selected timepoints. 
144 The chemical stability of thiamine in solution was monitored by measuring vitamin

145 concentration over time using a high performance liquid chromatography (HPLC) method

146 adapted from Xia et al. (Xia et al., 2006). A Waters 2690 Separations Module (Waters Corp.

147 Milford, MA) equipped with a Waters 2996 Photodiode Array detector (Waters Corp.) was used

148 with a $100 \mathrm{~mm}$ x $3.9 \mathrm{~mm}, 3.5 \mu \mathrm{m}$ particle size XTerra RP-C18 column (Waters Corp.). The

149 wavelength scan used was 235-400 nm. Mobile phase A: 0.1\% trifluoroacetic acid (TFA) in

150 water $(v / v)$ and mobile phase B: acetonitrile $(\mathrm{MeCN})$ were used with a flow rate of $1 \mathrm{~mL} / \mathrm{min}$ and

151 the following gradient method: 100/0 at $0 \mathrm{~min}, 97 / 3$ at $4 \mathrm{~min}$ (linear), 90/10 at 6 min (linear),

$152100 / 0$ at $10 \mathrm{~min}$ (linear), and 100/0 at $15 \mathrm{~min}$. Prior to analysis, solutions were removed from

153 controlled temperature storage, cooled in an ice bath, and diluted with mobile phase A to an

154 estimated thiamine concentration of $500 \mathrm{ppm}$, or $0.5 \mathrm{mg} / \mathrm{mL}$. Standard curves of TMN and

$155 \mathrm{TClHCl}\left(\mathrm{R}^{2}>0.999\right)$ at a concentration range of $10 \mathrm{ppm}$ to $1000 \mathrm{ppm}$ were prepared prior to

156 each day of analysis and used to calculate the concentration of each sample. Integration was

157 performed at $254 \mathrm{~nm}$.

158

$159 \quad 2.6$ Reaction Kinetics:

160 To understand the kinetics of thiamine loss due to specific treatments, the data collected

161 on the concentration of thiamine remaining in solution over time from the different initial

162 solution concentrations and storage temperatures were applied to first-order reaction kinetic

163 models, and the Arrhenius equation was used to model temperature-dependence of the reaction

164 rate constants. Microsoft Excel 2016 (Redmond, WA) was used for the calculations. 
166 kinetics (Gregory III, 2008; Mauri, Alzamora, Chirife, \& Tomio, 1989) wherein thiamine

167 concentration is described by:

$$
\ln \frac{x}{x_{0}}=-k t
$$

169 where $x$ is the concentration of thiamine at time $t$ (days), $x_{0}$ is the initial thiamine concentration,

170 and $k$ is the reaction rate constant $\left(\right.$ days $\left.^{-1}\right)$. The Arrhenius equation can be used to describe

171 temperature dependence of rate constant $k$ :

$$
k=A e^{\frac{-E_{a}}{R T}}
$$

173 where $k$ is the reaction rate constant $\left(\right.$ days $\left.^{-1}\right), A$ is the frequency factor of collision, $E_{a}$ is the

174 activation energy $(\mathrm{kJ} / \mathrm{mol}), R$ is the gas constant $(8.3145 \mathrm{~J} / \mathrm{mol} \cdot \mathrm{K})$, and $T$ is temperature $(\mathrm{K})$.

175 Since some foods have multiple degradation patterns that may have different temperature

176 dependencies, it is possible to find non-linear Arrhenius plots (Gregory III, 2008), and therefore

177 nonlinear Arrhenius plots were also considered.

\section{7 pH Measurement:}

180 The $\mathrm{pH}$ of solutions containing both vitamin forms, at all concentrations, and at all

181 temperatures, was measured to document how these variables affected the $\mathrm{pH}$. The $\mathrm{pH}$ of each

182 solution was measured in duplicate at all temperatures studied using an Orion pH probe

183 (ThermoScientific) that had been calibrated from $\mathrm{pH} 5$ to 7 for TMN and pH 1 to 4 for TClHCl

184 using calibration standards obtained from Fisher Scientific.

185

\subsection{Photography and color analysis:}


The color of the TMN and TClHCl solutions was documented in solutions removed

188 from the different storage temperatures. Samples were photographed at their endpoints in

189 a Deep Professional LED Photography light box using an iPhone 6s camera. The Hunter L,

$190 \mathrm{a}$, and b color scale values of the solutions were determined by using the Color Companion

191 iPhone application as described in Li et al. (Li, Taylor, Ferruzzi, \& Mauer, 2013; Li, Taylor, \&

192 Mauer, 2014) to analyze the photographs. In this color scale, L represents lightness (in

193 percent), a represents red (positive) vs. green (negative), and b represents yellow

194 (positive) vs. blue (negative) colors.

\subsection{Sensory Study of Odor Differences between Degraded Vitamin Solutions:}

197 Thiamine degradation is known to produce aromas and flavors (Buttery et al., 1984;

198 Dwivedi \& Arnold, 1973). To determine if differences in the odors produced by degraded TMN

199 and TClHCl could be detected by untrained panelists, $5 \mathrm{mg} / \mathrm{mL}$ solutions of each vitamin salt

200 form were again prepared in the $20 \mathrm{~mL}$ amber vials with PE cone-lined caps, heated for 2 days at

$20180^{\circ} \mathrm{C}$, and frozen until the day of the sensory test. These conditions were chosen as a

202 representation of the odor produced by each vitamin salt form, and the amount of thiamine

203 degradation in these samples was determined by HPLC.

204 Eligibility requirements for participants in the sensory test included no food allergies or 205 sensitivities, no known problems with sense of smell or taste, and no illness that may interfere

206 with smelling capabilities. All procedures were approved by the Purdue University Human

207 Subjects Research Protection Institutional Review Board as exempt under category 6 (taste and

208 food quality evaluation and consumer acceptance studies). Samples (5 mL, in capped amber

209 vials) were thawed at ambient temperature for 2 hours prior to the sensory analysis. The amber 
210 vials prevented color changes from affecting responses, and 3-digit codes were used for blinding

211 purposes. A two-alternative forced choice test was used to evaluate which sample smelled

212 stronger. Participants were presented with two vials (one containing each vitamin form) in

213 counterbalanced order and instructed to: "Start with the sample on the left. Open the bottle and

214 smell the cap. Then put the cap back on the bottle. Then open the bottle on the right and smell

215 the cap. Then put the cap back on the bottle. Which sample smelled stronger? You may smell

216 the samples again if you need to, but please smell just the cap.” Instructing participants to smell

217 only the cap of the vials ensured that smelling techniques were more consistent across all

218 participants.

219 After selecting the sample with the stronger smell, participants were given the option to

220 describe the odor of the stronger smelling sample. This was done to surreptitiously determine if

221 the participants found the samples to be unpleasant without biasing them for or against the

222 “stronger” sample.

223 Data were analyzed by GraphPad Software using a two-tailed binomial distribution with

$224 \alpha=0.05$. Using a rearrangement of Abbott's formula to adjust for chance (Lawless \& Heymann,

225 2010), 75\% of the participants needed to select the same sample as "stronger" in order to

226 conclude that participants found the aroma of one sample stronger than the other. This formula

227 was also used to determine the percentage of participants who were true discriminators.

2292.10 Statistical Analysis:

230 Samples were prepared and analyzed in triplicate for each time point of analysis. Single-

231 variable ANOVA using SAS 9.4 (SAS Institute, Cary, NC) was used to determine significant

232 differences in percent thiamine remaining between the initial solution and the degraded sample 
233 over time, between varying concentrations of solution at each time point, between both salt

234 forms, and between temperatures. Single-variable ANOVA was also used to determine

235 significant differences in $\mathrm{pH}$ and color change. Regression analysis was used to determine 95\%

236 confidence intervals for kobs values. Differences were determined using Tukey's post hoc test

237 for multiple comparisons at a significance level of $\alpha=0.05$.

239 3. Results \& Discussion

$240 \quad 3.1$ Effects of Concentration and Temperature on Stability of Thiamine in TMN Solutions:

241 Both temperature and concentration significantly $(\mathrm{p}<0.05)$ affected thiamine stability in

242 TMN solutions. Typical degradation profiles of thiamine across varying TMN solution

243 concentrations are shown in Figure 2. Increasing temperature increased thiamine degradation

244 rates at all TMN concentrations. Thiamine degraded in an exponential manner for all

245 concentrations of TMN solutions at all temperatures. Degradation patterns were related to the

246 concentration of thiamine in solution, with more thiamine degradation occurring in solutions

247 with higher TMN concentrations. As an example, in TMN solutions stored at $80^{\circ} \mathrm{C}$, solutions

248 containing the lowest TMN concentration, $1 \mathrm{mg} / \mathrm{mL}$, had $48 \%$ thiamine remaining after 7 days

249 (the least degradation), while solutions containing the most TMN (27 mg/mL) exhibited the

250 greatest degradation (31\% thiamine remaining) (Figure 2). A table containing all the thiamine

251 percent remaining data from all TMN solution concentrations at all temperatures is included in

252 the supplementary material (Table S1).

253 A clear trend was found at all temperatures that indicated there was a relationship

254 between increasing concentration and decreasing stability of thiamine in TMN solutions. This

255 finding conflicts with older reports that increasing thiamine concentrations in solutions adjusted 
256 to pH 6 resulted in increasing thiamine stability (Farrer, 1947; McIntire \& Frost, 1944).

257 Differences between those studies and this one include: lower concentrations in the previous

258 reports (the $\mu \mathrm{g} / \mathrm{mL}$ scale rather than the $\mathrm{mg} / \mathrm{mL}$ scale), and controlled $\mathrm{pH}$ versus unmodified $\mathrm{pH}$.

259 Controlling pH using a buffer system would be beneficial to better understand the dependency of

260 TMN stability on $\mathrm{pH}$ independently from TMN concentration. However, this study did not

261 explore buffer systems due to the possibility of thiamine interactions with the buffer affecting the

262 degradation kinetics. The $\mathrm{pH}$ of TMN solutions in this study ranged from 5.36 to 6.96 due to the

263 range of concentrations studied (Table 2). It is likely that $\mathrm{pH}$, rather than concentration, was the

264 main reason for differences in stability.

265 The thiamine degradation patterns found in all TMN solution concentrations and

266 temperature treatments were consistent with those reported in previous TMN studies (Gregory

267 III, 2008; Mauri et al., 1989), showing apparent first-order reaction kinetics (a typical example is

268 shown in Figure 3). As expected, reactions proceeded faster as temperature increased. High

269 correlations in linear regressions of the natural log of percent thiamine remaining over time for

270 all TMN concentrations and temperature treatments were obtained $\left(\mathrm{R}^{2}=0.86-0.99\right)$. These

271 results confirmed that the initial thiamine degradation in TMN solutions followed first-order

272 reaction kinetics. Reaction rate constants, or kobs values, were obtained using linear regressions

273 and eq 1 (Arrhenius plots shown in Figure 4), and t9o values were calculated using each

274 respective rate constant to describe the time it took for $10 \%$ of thiamine to degrade, or when $90 \%$

275 of the initial concentration of thiamine remained. The $\mathrm{k}_{\text {obs }}$ and t90 values are provided in Table

276 3. After the initial degradation which ended when the samples had approximately $40 \% \mathrm{TMN}$

277 remaining, the first order reaction rate was lost. This was likely due to interactions of thiamine

278 with increasing amounts of degradation products along with change in concentration (Ahmad et 
279 al., 2018; Dhakal, Balasubramaniam, Ayvaz, \& Rodriguez-Saona, 2018) . While kinetic

280 parameters of thiamine degradation have been estimated using an endpoints method in food

281 systems (Peleg, Normand, \& Goulette, 2016), which would require a smaller number of

282 experimental data points than used in this study and provide useful information on amount of

283 thiamine remaining in the system, such an approach assumes first order reaction rate and thus

284 could miss inflection points during the course of thiamine degradation when the first order 285 reaction rate is lost.

286 HPLC chromatograms of TMN solutions before and after storage treatments (and

287 degradation) are provided in the supplementary material (Figure S1) to facilitate comparisons of

288 the number and retention time of degradation peaks between TMN and TClHCl solutions. The

289 main thiamine degradation peaks in the TMN solutions were found at retention times of

290 approximately 3.26, 4.08, 5.79, 8.15, and $8.28 \mathrm{~min}$. L, a, and b values that documented the color

291 of TMN $27 \mathrm{mg} / \mathrm{mL}$ solutions over time are included in Table 4, and photographs are included in

292 the supplementary material (Figure S2). Little color change was found in TMN solutions

293 wherein a large proportion of the thiamine had degraded. For example, when only $31 \%$ of

294 thiamine remained in the TMN $27 \mathrm{mg} / \mathrm{mL}$ solution, after 7 days at $80^{\circ} \mathrm{C}$, only a slightly yellow

295 color in solution was present.

297 3.2 Effects of Concentration and Temperature on Stability of Thiamine in TClHCl 298 Solutions:

299 Thiamine stability in TClHCl solutions was also significantly $(\mathrm{p}<0.05)$ affected by 300 temperature, with increasing temperature resulting in faster degradation. However, no trends 301 were found between thiamine stability and the concentration of $\mathrm{TClHCl}$ in solution across all 
302 temperatures. The $\mathrm{pH}$ of $\mathrm{TClHCl}$ solutions in this study ranged from 1.12 to 3.59 , due to the

303 range of concentrations studied (Table 2). A typical degradation profile of TClHCl in varying

304 concentrations of solution at $80^{\circ} \mathrm{C}$ is shown in Figure 5. Thiamine in solutions across all

305 concentrations of TClHCl degraded in an exponential manner. A table containing all the

306 thiamine percent remaining data from all $\mathrm{TClHCl}$ solution concentrations at all temperatures is

307 provided in the supplementary material (Table S2).

The thiamine degradation patterns found in all TClHCl solution concentrations and

309 temperature treatments were consistent with those reported in the literature for TClHCl (Gregory

310 III, 2008; Mauri et al., 1989). Similar to the findings for thiamine stability in TMN solutions,

311 apparent first-order reaction kinetics were found for thiamine in $\mathrm{TClHCl}$ solutions (Figure 6),

312 and the first order reaction rate was lost after reactions had proceeded to approximately $40 \%$

313 thiamine remaining due to possible interactions with new solution components (thiamine

314 degradation products) (Ahmad et al., 2018; Dhakal et al., 2018). The degradation of thiamine in

$315 \mathrm{TClHCl}$ solutions was slower than in the TMN solutions, and thus only values from $60^{\circ} \mathrm{C}, 70^{\circ} \mathrm{C}$,

316 and $80^{\circ} \mathrm{C}$ were used for reaction kinetics calculations. High correlations in linear regressions of

317 the natural log of percent thiamine remaining over time for all $\mathrm{TClHCl}$ concentrations and

318 temperature treatments were obtained $\left(\mathrm{R}^{2}=0.79-0.99\right)$, which again confirmed the first-order

319 reaction kinetics of the initial thiamine degradation. Reaction rate constants, or k $k_{\text {obs }}$ values, were

320 obtained using linear regressions and eq 1 (Arrhenius plots are shown in Figure 7), and t9o values

321 were calculated to describe the time it took for $10 \%$ of thiamine to degrade, as shown in Table 3.

322 HPLC chromatograms of TClHCl solutions before and after storage treatments (and

323 degradation) are provided in the supplementary material (Figure S1) to facilitate the comparison

324 of the degradation peaks of thiamine in TClHCl and TMN solutions. The main thiamine 
325 degradation peaks found in $\mathrm{TClHCl}$ solutions were at retention times of approximately 2.13,

326 4.05. 5.72, and $6.95 \mathrm{~min}$. The $\mathrm{L}$, a, and b values that documented the color of selected TClHCl

327 solutions after storage are included in Table 4, and photographs of the color change are included

328 in the supplementary material (Figure S2). Unlike what was found in the TMN solutions, much

329 more color change was found in the TClHCl solutions, even when less thiamine had degraded.

330 For example, when $56 \%$ of thiamine in TClHCl $27 \mathrm{mg} / \mathrm{mL}$ solutions remained after 31 days at

$33180^{\circ} \mathrm{C}$, the solutions were nearly black, compared to minimal color change when more thiamine

332 had degraded in a shorter timeframe in $27 \mathrm{mg} / \mathrm{mL}$ TMN solutions (31\% thiamine remaining after

3337 days at $80^{\circ} \mathrm{C}$ in solutions that were light yellow). After only 5 hours at $80^{\circ} \mathrm{C}$, a $500 \mathrm{mg} / \mathrm{mL}$

334 solution of TClHCl in which no significant degradation of thiamine was found had a very similar

335 color to that same $27 \mathrm{mg} / \mathrm{mL}$ TMN solution with only 31\% thiamine remaining. The color

336 changes found in solutions of $\mathrm{TMN}$ and $\mathrm{TClHCl}$ at various points during degradation were

337 significantly different $(\mathrm{p}<0.05)$. The difference in color change was attributed to the different

338 degradation products that were formed by the different thiamine salts, exemplified by their

339 differing HPLC chromatograms.

340

3413.3 Sensory Study of Odor Differences between Degraded Vitamin Solutions:

342 Throughout the course of the thiamine degradation studies, differences in both the color

343 and aroma of TMN and $\mathrm{TClHCl}$ solutions were noted by the investigators, in addition to

344 documenting the differences in thiamine degradation rates and degradation product patterns in

345 the HPLC chromatograms. Investigators had noticed an intense odor and color change in

$346 \mathrm{TClHCl}$ solutions that occurred before thiamine degradation in the $\mathrm{TClHCl}$ solutions was even 
347 statistically significant. In contrast, the investigators had also noticed that TMN solutions had

348 not produced an intense smell or color change even when only $30 \%$ of thiamine remained.

349 To further pursue these initial observations, a sensory study was completed to determine

350 if a larger audience noted a difference in aromas produced by thiamine degradation in TMN and

351 TClHCl solutions. Using the two-alternative forced-choice test, 51 of 68 panelists chose the

$352 \mathrm{TClHCl}$ sample as having a stronger aroma than the TMN sample. Adjusting for chance, this

353 was sufficient to conclude that the TClHCl sample had a stronger aroma than the TMN sample.

354 From the adjusted Abbott’s formula (Lawless \& Heymann, 2010), 34 of the 68 panelists would

355 be considered true discriminators, indicating that approximately $50 \%$ of people should truly find

356 the TClHCl sample more potent. A two-tailed binomial test yielded $\mathrm{p}<0.0001$, again indicating

357 that the TClHCl solution had a significantly stronger aroma than the TMN solution (see

358 supplementary Figure S3). A cursory evaluation of the words used to describe the TClHCl

359 solution odor indicated that subjects found the aroma unfavorable. Descriptive words used by

360 panelists are provided in the supplementary material (Table S3). The percent thiamine remaining

361 in each of these solutions, as determined by HPLC, was 66\% thiamine remaining in the TMN

362 solution with no significant degradation found in the TClHCl solution. Thus, it was concluded

363 that the thiamine degradation products in $\mathrm{TClHCl}$ solutions had a significantly more potent odor

364 than the degradation products in TMN solutions.

365

\section{3.4 Comparison of Thiamine Stability in TMN and TCIHCI Solutions:}

367 There was a significant difference $(\mathrm{p}<0.05)$ in thiamine stability between TMN and

368 TClHCl solutions, as shown by the comparison graphs in Figure 8 and by kobs and t90 values

369 reported in Table 3. Thiamine in TMN solutions degraded faster than thiamine in TClHCl 
370 solutions, with more substantial differences in stability manifesting as the temperature increased

371 (Figure 8, Table S1, Table S2). The differences between the two salt forms were also

372 exemplified by sensory implications, including aroma and color change (Table 4, Figure S2).

373 Some possible degradation products that may contribute to differences in TMN and TClHCl

374 solutions were identified by Dwivedi and Arnold (1973), including thiochrome,

375 dihydrothiochrome, thioketones, pyrimidine and thiazole derivatives, and disulfides, among

376 others.

377 TMN and TClHCl salts dissociate in solution to become the thiamine cation (with one or

378 two positive charges, depending on $\mathrm{pH}$ (Figure 9)) and the respective anions. The main

379 differences in solution traits between these thiamine salt forms are the type of anion present and

380 the resulting solution $\mathrm{pH}$. The $\mathrm{pH}$ values of $\mathrm{TMN}$ and $\mathrm{TClHCl}$ solutions at all concentrations

381 and temperatures studied are shown in Table 2. It has been well-documented that $\mathrm{pH}$ affects

382 thiamine stability; specifically, thiamine is much more stable in acidic conditions than in

383 approximately neutral or alkaline conditions (Dwivedi \& Arnold, 1973; Farrer, 1947; Gregory

384 III, 2008; McIntire \& Frost, 1944). Thus, it was not surprising to find that thiamine in TClHCl

385 solutions was much more stable than thiamine in TMN solutions, since the TClHCl formed more 386 acidic solutions than the TMN.

387 It has also been reported that $\mathrm{pH}$ affects the degradation pathway of thiamine (Dwivedi \& 388 Arnold, 1972). Thiamine has a pK $\mathrm{a}_{\mathrm{a}}$ of 4.8 (for the pyrimidine N1 nitrogen) (Edwards et al., 389 2017). In acidic conditions $(\mathrm{pH}<6)$, degradation occurs by cleavage of the methylene bridge to

390 release intact pyrimidine and thiazole moieties; while in conditions above $\mathrm{pH}$ 6, degradation

391 involves the same cleavage, but also further fragmentation of the thiazole ring (Gregory III,

392 2008). These varying pathways support the observation of different degradation products 
393 formed in the close to neutral $\mathrm{pH}$ TMN solutions and the acidic TClHCl solutions, as noted in the

394 HPLC chromatograms (Figure S1). By comparing the retention times of the thiamine

395 degradation products in the HPLC chromatograms, common degradation products found in both

$396 \mathrm{TMN}$ and TClHCl solutions had retention times of approximately 4.05 and $5.75 \mathrm{~min}$, while

397 differences were found in degradation products appearing at 3.26, 8.15, and 8.28 $\min$ in TMN

398 solutions, and at 2.13 and $6.95 \mathrm{~min}$ in TClHCl solutions. These different degradation products

399 likely caused the differences in color and aroma between the TMN and TClHCl solutions.

400 Thiamine stability was significantly affected by TMN concentration, with thiamine

401 degradation rates increasing as the concentration of TMN increased. This observation was likely

402 more dependent on the changing solution pHs as TMN concentration increased rather than on the

403 solution concentration of the thiamine per se. It has been well-documented that there is a

404 dramatic decrease in stability of thiamine as $\mathrm{pH}$ reaches and exceeds $\mathrm{pH} 6.0$ (Feliciotti \&

405 Esselen, 1957; Mulley, Stumbo, \& Hunting, 1975; Williams \& Ruehle, 1935). This change in

406 stability is a result of the $\mathrm{pK}_{\mathrm{a}}$ of thiamine (4.8). As illustrated in the speciation plot of thiamine

407 in Figure 9, the more stable protonated species of thiamine is present as a notable fraction in

408 acidic conditions up to approximately $\mathrm{pH}$ 6.0. As pH increases above 6.0, the less stable

409 unprotonated species of thiamine dominates, and the stability of thiamine dramatically decreases.

410 This noteworthy $\mathrm{pH}$ value (6.0) could be used to explain the dependence of thiamine stability on

411 TMN concentration since the $\mathrm{pH}$ values found for TMN solutions were between $\mathrm{pH} 5.36$ and

412 6.96. Small increases in $\mathrm{pH}$ due to increases in TMN concentration would have led to major

413 changes in the fraction of protonated/unprotonated thiamine species present, which in turn would

414 have caused the large decrease in thiamine stability that was found to be so dependent on TMN

415 concentration. Conversely, in the $\mathrm{pH}$ range found in $\mathrm{TClHCl}$ solutions (from 1.12 to 3.59), the 
416 protonated species of thiamine would have been predominant, which was likely why thiamine

417 was not only more stable in the TClHCl solutions but also exhibited no stability dependence on

418 TClHCl concentration.

419 Over a large range of temperatures, $\mathrm{pH}$ is known to vary slightly (Clark, 2017): as

420 temperature increases, $\mathrm{pH}$ decreases. As shown in Figure 10 and Table 2, this trend was found in

421 the TMN and TClHCl samples. Although this is of interest to note, it is not likely that this

422 temperature-dependent $\mathrm{pH}$ change significantly affected thiamine stability, especially since this

423 stability trend is in opposition to the effect of temperature. However, $\mathrm{K}_{\mathrm{w}}$ also changes with

424 temperature (Clark, 2017), meaning that although pH changes, acidity/alkalinity does not

425 change, which led to the conclusion that $\mathrm{pH}$ change with temperature was an inconsequential

426 factor in this thiamine stability study.

\section{3.5 Degradation Kinetics of Thiamine Salt Forms:}

429 The degradation kinetics of thiamine in various matrices (different from the solutions

430 studied here) have been reported, including solid state with varying water activities, controlling

431 for $\mathrm{pH}$, and in the presence of various humectants (Kamman, Labuza, \& Warthesen, 1981;

432 Labuza \& Kamman, 1982; Mauri, Alzamora, \& Tomio, 1992). Thiamine was generally reported

433 to have an activation energy of 20-30 kcal/mol (80-125 kJ/mol) (Kamman et al., 1981; Mauri et

434 al., 1992). When controlling for $\mathrm{pH}$, the activation energy was reported to be $27.4 \mathrm{kcal} / \mathrm{mol}$ at

$435 \mathrm{pH} 5.5$ and $29 \mathrm{kcal} / \mathrm{mol}$ at $\mathrm{pH} 4.0$ (Mauri et al., 1992). When specifically looking at the different

436 salt forms, activation energy was reported as $22.4 \mathrm{kcal} / \mathrm{mol}$ for TClHCl and $26.3 \mathrm{kcal} / \mathrm{mol}$ for

437 TMN, with the Ea decreasing as water activity increased (Labuza \& Kamman, 1982). This

438 difference in activation energies is the reason for the greater stability of TMN compared to 
$439 \mathrm{TClHCl}$ in the solid state, but these values do not agree with the stability trends of thiamine in

440 solution found in this study. In the current study, $\mathrm{pH}$ and vitamin form were assumed to

441 influence activation energy in solution, with the main factor being $\mathrm{pH}$ change due to variations in

442 the ionization of each thiamine salt in solution.

443 It was reported previously that thiamine degradation in buffered solutions from $50^{\circ} \mathrm{C}$ to

$444110^{\circ} \mathrm{C}$ exhibited no deviation from Arrhenius behavior (Farrer \& Morrison, 1949), but

445 temperatures below $50^{\circ} \mathrm{C}$ were not included in the study. In the current study, non-linear

446 Arrhenius plots were found to occur as the concentration of degradation products increased;

447 however, in the early stages of thiamine degradation linear Arrhenius plots were found. These

448 linear Arrhenius plots were used to calculate reaction kinetics. Using the $\mathrm{k}_{\text {obs }}$ values from

449 temperatures $25,40,60,70$, and $80^{\circ} \mathrm{C}$, the TMN activation energies were consistent with

450 previous reports, ranging from $21-25 \mathrm{kcal} / \mathrm{mol}$ (88-105 kJ/mol), dependent on concentration. All

451 values are included in Table 5. Using the kobs values from temperatures 60,70 , and $80^{\circ} \mathrm{C}$,

$452 \mathrm{TClHCl}$ activation energies were found to range from 21-32 kcal/mol (90-135 kJ/mol). While

453 these values are slightly higher than those previously reported, the extremely low $\mathrm{pH}$ found in

454 the TClHCl solutions was not studied elsewhere. The low $\mathrm{pH}$ values (1.12-3.59) and

455 consequently the predominance of the more stable protonated form of thiamine (Figure 9) led to

456 the higher stability of thiamine in TClHCl solutions observed in this study (for example, $91 \%$ of

$457 \mathrm{TClHCl}$ remained in the $10 \mathrm{mg} / \mathrm{mL}$ solution after 7 days at $80^{\circ} \mathrm{C}$ compared to $38 \% \mathrm{TMN}$

458 remaining in the same conditions). Additionally, the high thiamine stability in TClHCl solutions

459 at $25^{\circ} \mathrm{C}$ and $40^{\circ} \mathrm{C}$ allowed the use of only 3 (higher) temperatures for the kinetics calculations,

460 rather than the preferred 5 temperatures. However, the $\mathrm{R}^{2}$ values for the Arrhenius calculations

461 for TClHCl solutions were high correlations (0.87-0.99). All $\mathrm{E}_{\mathrm{a}}$ values are reported in Table 5. 
Overall, the reaction kinetics found in the current study agree reasonably well with

463 previous reports. TClHCl was found to have a higher activation energy than TMN, presumably

464 due to the difference in $\mathrm{pH}$ values between the two salt forms in solution. The low $\mathrm{pH}$

465 conditions in the TClHCl solutions studied caused the protonated thiamine species, the more

466 stable of the two species, to be predominately present in solution. The low $\mathrm{pH}$ samples had a

467 higher activation energy of thiamine degradation and were significantly $(\mathrm{p}<0.05)$ more stable

468 than thiamine in the close to neutral pH TMN solutions.

470 3.6 Potential Implications in Food Formulations:

471 Although the concentrations of thiamine investigated in this study were higher than

472 concentrations found in most food products, the implications for trends in thiamine stability at

473 different $\mathrm{pHs}$ and temperatures are relevant for foods naturally containing or fortified with

474 thiamine. Many food products act as acidic environments that will protect thiamine stability,

475 including fruit products and energy drinks. In these acidic conditions, no significant thiamine

476 degradation was found at ambient temperature over the 6 month period of this study. However,

477 there are also many food sources of thiamine that are close to neutral $\mathrm{pH}$ or slightly alkaline,

478 including milk, teas, beans, eggs, peas, and peanuts. The higher $\mathrm{pHs}$ in these foods may

479 contribute to degradation of thiamine during storage. For example, in close to neutral $\mathrm{pH}$ or

480 slightly alkaline samples at ambient temperatures, the t90 was 130-310 days, depending on $\mathrm{pH}$,

481 compared to t9o values that could not be calculated in acidic conditions due to lack of significant

482 degradation. While some products (e.g., fruits, yeast, meats, eggs, and legumes) naturally

483 contain thiamine, many other food products are enriched with the salt forms of thiamine

484 investigated in this study. Some of the products enriched with TMN or TClHCl that have close 
485 to neutral $\mathrm{pH}$ or slightly alkaline $\mathrm{pH}$ include various dairy products, powdered or liquid infant

486 formulas, dietary supplements, and enriched flour (Bettendorff, 2012). Enriched flours are

487 commonly combined with leavening agents in baked goods formulations, and these leavening

488 agents produce slightly alkaline conditions (Cauvain \& Young, 2006) which, as shown in this

489 study, provide an unstable environment for thiamine. Further heating these products, such as

490 during baking, could contribute to more thiamine degradation. Additionally, common food

491 products or dietary supplements with limited water but high thiamine content include nutritional

492 yeast, dried milk, infant formula, dried seaweed, and vitamin B complex supplements (U.S.

493 Department of Agriculture Agricultural Research Service, 2018). Since thiamine has the

494 potential to begin to dissolve in small amounts of water and is known to degrade faster in

495 solution than in the solid state (Hiatt et al., 2008), the thiamine found in these products may act

496 more like the thiamine in this study at high concentrations in the water present.

497 Although thiamine is often found in the presence of excipients in supplements or other

498 ingredients in food products that can improve (or worsen) chemical stability (Kandutsch \&

499 Baumann, 1953), the degradation kinetics found in this study for pure thiamine in solution

500 provide valuable information on the fundamental behavior of thiamine. Analyzing thiamine

501 stability in buffered solutions to control for $\mathrm{pH}$ or in the presence of co-formulated ingredients

502 would extend the implications of this study to more representative food systems and provide

503 useful information on additional factors that contribute to the stability and/or degradation of

504 thiamine.

505

506 4. Conclusions 
508 dissolved, the resulting solution $\mathrm{pH}$, and the storage temperature. All thiamine degradation was

509 found to follow first order reaction kinetics until degradation products were present in high

510 concentrations ( $<40 \%$ vitamin remaining), which were thought to alter the degradation pathway.

511 Thiamine in TClHCl solutions was found to be much more stable in all conditions than thiamine

512 in TMN solutions, which was attributed to the low $\mathrm{pH}$ of TClHCl solutions. Although acidic

513 conditions delayed the degradation of thiamine in solution, the low $\mathrm{pH}$ also altered the

514 degradation pathway and produced different degradation products than were found in close to

515 neutral $\mathrm{pH}$ conditions. This was demonstrated by differing peak positions in HPLC

516 chromatograms between solutions of TMN and TClHCl. Thiamine degradation products in

517 TClHCl solutions also contributed a potent odor and intense color change even before

518 degradation became significant $(\mathrm{p}<0.05)$. However, even with very large amounts of thiamine

519 degradation in TMN solutions, sensory impacts were minimal. This study developed shelf-life

520 studies that directly compared the stabilities and reaction kinetics of the two most common salt

521 forms of thiamine, used in dietary supplements and as food additives, as a function of

522 concentration and temperature. The results can aid in improving the understanding of thiamine

523 degradation in a variety of products that are enriched or fortified with thiamine.

\section{5. Acknowledgements}

526 The authors would like to acknowledge Ciera Crawford and Matt Allan for their generous

527 assistance with the sensory studies.

528 Funding: This work was financially supported by the United States Department of Agriculture

529 [grant number 2016-67017-24592]. 
Ahmad, I., Mobeen, M. F., Sheraz, M. A., Ahmed, S., Anwar, Z., Shaikh, R. S., . . Ali, S. M. (2018). Photochemical interaction of ascorbic acid and nicotinamide in aqueous solution: A kinetic study. Journal of Photochemistry and Photobiology B: Biology, 182, 115-121. doi: https://doi.org/10.1016/j.jphotobiol.2018.04.011

Ash, M. (2008). Handbook of food additives (3rd ed.. ed.). Endicott, NY: Endicott, NY : Synapse Information Resources.

Atkins, P., \& de Paula, J. (2006). Phase equilibria. In P. Atkins \& J. de Paula (Eds.), Physical chemistry for the life sciences (pp. 104-150). New York, NY: W. H. Freeman and Company.

Ball, G. F. M. (2006). Vitamins in foods : analysis, bioavailability, and stability. Boca Raton, FL: CRC/Taylor \& Francis.

Baumgartner, T. G., Henderson, G. N., Fox, J., \& Gondi, U. (1997). Stability of ranitidine and thiamine in parenteral nutrition solutions. Nutrition, 13(6), 547-553.

Bettendorff, L. (2012). Thiamin Present Knowledge in Nutrition (pp. 261-279): WileyBlackwell.

Buttery, R. G., Haddon, W. F., Seifert, R. M., \& Turnbaugh, J. G. (1984). Thiamin odor and bis(2-methyl-3-furyl) disulfide. J. Agric. Food Chem., 32(3), 674-676. doi: 10.1021/jf00123a061

Cauvain, S. P., \& Young, L. S. (2006). Ingredients and their influences. In S. P. Cauvain \& L. S. Young (Eds.), Baked products science, technology and practice: Oxford : Blackwell.

ChemSpider. (2015). Thiamine: Royal Society of Chemistry.

Clark, J. (2017). Temperature dependence of the $\mathrm{pH}$ of pure water. LibreTexts

Dennison, D., Kirk, J., Bach, J., Kokoczka, P., \& Heldman, D. (1977). Storage stability of thiamin and riboflavin in a dehydrated food system. Journal of Food Processing and Preservation, 1(1), 43-54.

Dhakal, S., Balasubramaniam, V. M., Ayvaz, H., \& Rodriguez-Saona, L. E. (2018). Kinetic modeling of ascorbic acid degradation of pineapple juice subjected to combined pressurethermal treatment. Journal of Food Engineering, 224, 62-70. doi: https://doi.org/10.1016/j.jfoodeng.2017.12.016

Dwivedi, B. K., \& Arnold, R. G. (1972). Chemistry of thiamine degradation: mechanisms of thiamine degradation in a model food system. Journal of Food Science, 37(6), 886-888. doi: 10.1111/j.1365-2621.1972.tb03694.x

Dwivedi, B. K., \& Arnold, R. G. (1973). Chemistry of thiamine degradation in food products and model systems: a review. [Review]. Journal of Agricultural and Food Chemistry, 21(1), 54-60. doi: 10.1021/jf60185a004

Edwards, K. A., Tu-Maung, N., Cheng, K., Wang, B., Baeumner, A. J., \& Kraft, C. E. (2017). Thiamine Assays-Advances, Challenges, and Caveats (Vol. 6, pp. 178-191).

Farrer, K. T. (1947). The thermal destruction of vitamin B1: the influence of the concentration of buffer salts on the rate of destruction of aneurin at 100 degrees. The Biochemical Journal, 41(2), 167. 
Farrer, K. T., \& Morrison, P. G. (1949). The thermal destruction of vitamin B1: the effect of temperature and oxygen on the rate of destruction of aneurin. Australian Journal of Experimental Biology \& Medical Science, 27(5).

Feliciotti, E., \& Esselen, W. (1957). Thermal destruction rates of thiamine in pureed meats and vegetables. Food Technology, 11(2), 77-84.

Gregory III, J. F. (2008). Vitamins. In S. Damodaran, K. L. Parkin \& O. R. Fennema (Eds.), Fennema's food chemistry (4th ed., pp. 439-521). Boca Raton: CRC Press/Taylor \& Francis.

Hiatt, A. N., Ferruzzi, M. G., Taylor, L. S., \& Mauer, L. J. (2008). Impact of deliquescence on the chemical stability of vitamins B(1), B(6), and C in powder blends. [Article]. Journal of Agricultural and Food Chemistry, 56(15), 6471-6479. doi: 10.1021/jf800709f

Institute of Medicine. (1998). Thiamin Dietary reference intakes for thiamin, riboflavin, niacin, vitamin $B_{6}$, folate, vitamin $B_{12}$, pantothenic acid, biotin, and choline. Washington, D.C.: National Academy Press.

Kamman, J. F., Labuza, T. P., \& Warthesen, J. J. (1981). Kinetics of thiamin and riboflavin loss in pasta as a function of constant and variable storage conditions. Journal of Food Science, 46(5), 1457-1461. doi: 10.1111/j.1365-2621.1981.tb04197.x

Kandutsch, A. A., \& Baumann, C. A. (1953). Factors affecting the stability of thiamine in a typical laboratory diet. The Journal of nutrition, 49(2), 209.

Labuza, T. P., \& Kamman, J. F. (1982). Comparison of stability of thiamin salts at high temperature and water activity. Journal of Food Science, 47(2), 664-665. doi: 10.1111/j.1365-2621.1982.tb10146.x

Labuza, T. P., \& Tannenbaum, S. R. (1972). Nutrient losses during drying and storage of dehydrated foods. Critical Reviews in Food Science \& Nutrition, 3(2), 217-240.

Lawless, H. T., \& Heymann, H. (2010). Similarity, equivalence testing, and discrimination theory. In H. T. Lawless \& H. Heymann (Eds.), Sensory evaluation of food: principles and practices (2nd ed.. ed., pp. 101-122). New York: New York : Springer.

Li, N., Taylor, L. S., Ferruzzi, M. G., \& Mauer, L. J. (2013). Color and chemical stability of tea polyphenol (-)-epigallocatechin-3-gallate in solution and solid states. Food Research International, 53(2), 909-921. doi: https://doi.org/10.1016/j.foodres.2012.11.019

Li, N., Taylor, L. S., \& Mauer, L. J. (2014). The physical and chemical stability of amorphous (-)-epi-gallocatechin gallate: effects of water vapor sorption and storage temperature. Food Research International, 58, 112-123. doi: https://doi.org/10.1016/j.foodres.2014.01.043

Mauri, L. M., Alzamora, S. M., Chirife, J., \& Tomio, M. J. (1989). Review: kinetic parameters for thiamine degradation in foods and model solutions of high water activity. International Journal of Food Science \& Technology, 24(1), 1-9. doi: 10.1111/j.13652621.1989.tb00613.x

Mauri, L. M., Alzamora, S. M., \& Tomio, J. M. (1992). Effect of electrolytes on the kinetics of thiamine loss in model systems of high water activity. Food Chemistry, 45(1), 19-23. doi: 10.1016/0308-8146(92)90006-N

McIntire, F. C., \& Frost, D. V. (1944). Thiamin stability: effect of amino acids and related compounds and of thiamin concentration. Journal of the American Chemical Society, 66(8), 1317-1318. doi: 10.1021/ja01236a033 
617 Mulley, E., Stumbo, C., \& Hunting, W. (1975). Effect of $\mathrm{pH}$ and form of the vitamin on its rate 618 of destruction. Journal of Food Science, 40(5), 989-992.

619 Peleg, M., Normand, M. D., \& Goulette, T. R. (2016). Calculating the degradation kinetic parameters of thiamine by the isothermal version of the endpoints method. Food Research International, 79, 73-80. doi: http://dx.doi.org/10.1016/j.foodres.2015.12.001

Prinzo, Z. W. (1999). Thiamine deficiency and its prevention and control in major emergencies Micronutrient series: World Health Organization (WHO). Department of Nutrition for Health and Development; Office of the United Nations High Commissioner for Refugees (UNHCR).

Shepherd, S. J., \& Gibson, P. R. (2013). Nutritional inadequacies of the gluten-free diet in both recently-diagnosed and long-term patients with coeliac disease. Journal of Human Nutrition and Dietetics, 26(4), 349-358. doi: doi:10.1111/jhn.12018

Spitzer, V., \& Schweigert, F. (2007). Vitamin basics the facts about vitamins in nutrition. DSM Nutritional Products Ltd, Germany.

U.S. Department of Agriculture Agricultural Research Service. (2018). USDA national nutrient database for standard reference. Retrieved March 2, 2018, from Nutrient Data Laboratory Home Page http://www.ars.usda.gov/nutrientdata

U.S. Food \& Drug Administration. (2018). FDA vitamins and minerals chart

Williams, R. R., \& Ruehle, A. E. (1935). Studies of crystalline vitamin B1: presence of quaternary nitrogen. Journal of the American Chemical Society, 57(10), 1856-1860. doi: 10.1021/ja01313a029

Xia, F., Hong, P., Alden, B., Boissel, C., Swanson, D., Chambers, E., ... Walter, T. (2006). Improvements in reversed-phase HPLC columns designed for polar compound. Paper presented at the HPLC, San Francisco, CA.

643 
Table 1. Solid state property comparison between TMN and TClHCl.

Thiamine Mononitrate

Thiamine Chloride Hydrochloride

\begin{tabular}{ccc}
\hline Molecular weight $^{\mathbf{1}}$ & $327.36 \mathrm{~g} / \mathrm{mol}$ & $337.26 \mathrm{~g} / \mathrm{mol}$ \\
Melting point $^{\mathbf{1}^{2}}$ & $196-200^{\circ} \mathrm{C}$ & $248^{\circ} \mathrm{C}$ \\
$\begin{array}{c}\text { Deliquescence point } \\
\mathbf{2}\end{array}$ & $98.5 \% \mathrm{RH}$ & $88 \% \mathrm{RH}$ \\
Aqueous solubility & $30 \mathrm{mg} / \mathrm{mL}$ & $570 \mathrm{mg} / \mathrm{mL}$ \\
\hline
\end{tabular}

${ }^{1}$ (ChemSpider, 2015)

2 (Hiatt et al., 2008) 
Table 2. $\mathrm{pH}$ values of $\mathbf{A}$ ) pure water and $\mathbf{B}) \mathrm{TMN}$ and $\mathrm{TClHCl}$ solutions at each concentration and temperature studied. Uppercase superscript letters on values denote statistical significance within temperatures for each vitamin salt form (down columns). Lowercase superscript letters on values denote statistical significance within concentration for each vitamin salt form (across rows).

A)

\begin{tabular}{lcccccc}
\hline & $\mathbf{2 5}^{\circ} \mathbf{C}$ & $\mathbf{3 0}^{\circ} \mathbf{C}$ & $\mathbf{4 0}^{\circ} \mathbf{C}$ & $\mathbf{5 0}^{\circ} \mathbf{C}$ & $\mathbf{1 0 0}^{\circ} \mathbf{C}$ & Ref \\
\hline Pure Water & 7.00 & 6.92 & 6.77 & 6.63 & 6.14 & (Clark, 2017) \\
\hline
\end{tabular}

B)

\begin{tabular}{|c|c|c|c|c|c|c|}
\hline $\begin{array}{c}\text { Vitamin } \\
\text { Salt Form }\end{array}$ & $\begin{array}{c}\text { Concentration } \\
(\mathrm{mg} / \mathrm{mL})\end{array}$ & $25^{\circ} \mathrm{C}$ & $40^{\circ} \mathrm{C}$ & $60^{\circ} \mathrm{C}$ & $70^{\circ} \mathrm{C}$ & $80^{\circ} \mathrm{C}$ \\
\hline \multirow[t]{5}{*}{ TMN } & 1 & $6.42 \pm 0.04^{\mathrm{Aa}}$ & $6.23 \pm 0.09^{\mathrm{Aa}}$ & $5.95 \pm 0.07^{\mathrm{Ab}}$ & $5.76 \pm 0.03^{\mathrm{Ab}}$ & $5.46 \pm 0.07^{\mathrm{ABc}}$ \\
\hline & 5 & $6.6 \pm 0.3^{\mathrm{Aa}}$ & $6.2 \pm 0.4^{\mathrm{Aab}}$ & $5.9 \pm 0.3^{\mathrm{Aab}}$ & $5.6 \pm 0.2^{\mathrm{Aab}}$ & $5.36 \pm 0.05^{\mathrm{Bb}}$ \\
\hline & 10 & $6.8 \pm 0.2^{\mathrm{Aa}}$ & $6.5 \pm 0.2^{\text {Aab }}$ & $6.1 \pm 0.1^{\mathrm{Abc}}$ & $5.8 \pm 0.1^{\mathrm{Ac}}$ & $5.5 \pm 0.2^{\mathrm{ABC}}$ \\
\hline & 20 & $6.93 \pm 0.03^{\mathrm{Aa}}$ & $6.57 \pm 0.09^{\mathrm{Ab}}$ & $6.14 \pm 0.09^{\mathrm{Ac}}$ & $5.9 \pm 0.1^{\text {Acd }}$ & $5.61 \pm 0.05^{\mathrm{ABd}}$ \\
\hline & 27 & $6.96 \pm 0.03^{\mathrm{Aa}}$ & $6.67 \pm 0.03^{\mathrm{Aa}}$ & $6.24 \pm 0.08^{\mathrm{Ab}}$ & $5.86 \pm 0.09^{\mathrm{Ac}}$ & $5.8 \pm 0.1^{\mathrm{Ac}}$ \\
\hline \multirow[t]{8}{*}{ TClHCI } & 1 & $3.59 \pm 0.03^{\mathrm{Aa}}$ & $3.2 \pm 0.1^{\text {Aab }}$ & $2.9 \pm 0.1^{\mathrm{Abc}}$ & $2.6 \pm 0.1^{\mathrm{Abc}}$ & $2.6 \pm 0.2^{\mathrm{Ac}}$ \\
\hline & 5 & $3.30 \pm 0.01^{\mathrm{Ba}}$ & $2.8 \pm 0.1^{\mathrm{Aab}}$ & $2.5 \pm 0.1^{\mathrm{ABbc}}$ & $2.2 \pm 0.1^{\mathrm{Bc}}$ & $2.2 \pm 0.2^{\mathrm{ABC}}$ \\
\hline & 10 & $3.17 \pm 0.00^{\mathrm{Ca}}$ & $2.67 \pm 0.08^{\mathrm{Bb}}$ & $2.3 \pm 0.1^{\mathrm{BCc}}$ & $1.95 \pm 0.08^{\mathrm{BCcd}}$ & $1.89 \pm 0.08^{\mathrm{BCd}}$ \\
\hline & 20 & $3.05 \pm 0.00^{\mathrm{Da}}$ & $2.51 \pm 0.00^{\mathrm{BCb}}$ & $2.19 \pm 0.04^{\mathrm{BCc}}$ & $1.97 \pm 0.07^{\mathrm{BCcd}}$ & $1.9 \pm 0.1^{\mathrm{BCd}}$ \\
\hline & 27 & $2.99 \pm 0.01^{\mathrm{Da}}$ & $2.46 \pm 0.02^{\mathrm{BCb}}$ & $2.14 \pm 0.01^{\mathrm{BCc}}$ & $2.0 \pm 0.1^{\mathrm{BCcd}}$ & $1.8 \pm 0.1^{\mathrm{BCDd}}$ \\
\hline & 100 & $2.77 \pm 0.01^{\mathrm{Ea}}$ & $2.36 \pm 0.02^{\mathrm{Cb}}$ & $1.9 \pm 0.1^{\mathrm{CDc}}$ & $1.7 \pm 0.1^{\mathrm{CDcd}}$ & $1.51 \pm 0.03^{\mathrm{CDEd}}$ \\
\hline & 300 & $2.53 \pm 0.01^{\mathrm{Fa}}$ & $2.05 \pm 0.06^{\mathrm{Db}}$ & $1.6 \pm 0.1^{\mathrm{Dc}}$ & $1.44 \pm 0.03^{\text {DEcd }}$ & $1.28 \pm 0.06^{\mathrm{DEd}}$ \\
\hline & 500 & $2.35 \pm 0.03^{\mathrm{Ga}}$ & $1.93 \pm 0.01^{\mathrm{Db}}$ & $1.5 \pm 0.2^{\mathrm{Dc}}$ & $1.3 \pm 0.1^{\mathrm{Ecd}}$ & $1.12 \pm 0.09^{\mathrm{Ed}}$ \\
\hline
\end{tabular}




\begin{tabular}{|c|c|c|c|c|c|c|c|}
\hline $\begin{array}{l}\text { Vitamin } \\
\text { Salt Form }\end{array}$ & $\begin{array}{c}\text { Temperature } \\
\left({ }^{\circ} \mathrm{C}\right)\end{array}$ & & $1 \mathrm{mg} / \mathrm{mL}$ & $5 \mathrm{mg} / \mathrm{mL}$ & 10 mg/mL & $20 \mathrm{mg} / \mathrm{mL}$ & $27 \mathrm{mg} / \mathrm{mL}$ \\
\hline \multirow[t]{15}{*}{ TMN } & \multirow[t]{3}{*}{25} & $\mathrm{k}_{\mathrm{obs}}{ }^{*}\left(\right.$ day $\left.^{-1}\right)$ & $\begin{array}{l}3.4 \times 10^{-4} \pm \\
0.5 \times 10^{-4} \mathrm{Aa}\end{array}$ & $\begin{array}{c}6.3 \times 10^{-4} \pm \\
0.6 \times 10^{-4} \mathrm{Abc}\end{array}$ & $\begin{array}{l}8.1 \times 10^{-4} \pm \\
0.1 \times 10^{-4} \mathrm{Ac}\end{array}$ & $\begin{array}{c}4.8 \times 10^{-4} \pm \\
0.5 \times 10^{-4} \mathrm{Aab}\end{array}$ & $\begin{array}{l}7.2 \times 10^{-4} \pm \\
0.8 \times 10^{-4} \mathrm{Ac}\end{array}$ \\
\hline & & $\mathrm{R}^{2}$ & 0.8601 & 0.9560 & 0.8551 & 0.9259 & 0.9309 \\
\hline & & $\mathrm{t}_{90}{ }^{* *}$ (days) & 310 & 167 & 130 & 220 & 146 \\
\hline & \multirow[t]{3}{*}{40} & $\mathrm{k}_{\mathrm{obs}}\left(\mathrm{day}^{-1}\right)$ & $\begin{array}{l}1.74 \times 10^{-3} \pm \\
0.7 \times 10^{-4} \mathrm{Aa}\end{array}$ & $\begin{array}{l}3.1 \times 10^{-3} \pm \\
0.2 \times 10^{-3} \mathrm{Aa}\end{array}$ & $\begin{array}{l}5.1 \times 10^{-3} \pm \\
0.4 \times 10^{-3} \mathrm{Ab}\end{array}$ & $\begin{array}{l}7.6 \times 10^{-3} \pm \\
0.6 \times 10^{-3} \mathrm{Ac}\end{array}$ & $\begin{array}{l}9.7 \times 10^{-3} \pm \\
0.1 \times 10^{-3} \mathrm{Ad}\end{array}$ \\
\hline & & $\mathrm{R}^{2}$ & 0.9858 & 0.9680 & 0.9629 & 0.9554 & 0.9321 \\
\hline & & $\mathrm{t}_{90}$ (days) & 60.6 & 34.0 & 20.7 & 13.9 & 10.9 \\
\hline & \multirow[t]{3}{*}{60} & $\mathrm{k}_{\mathrm{obs}}\left(\mathrm{day}^{-1}\right)$ & $\begin{array}{l}1.7 \times 10^{-2} \pm \\
0.1 \times 10^{-2} \mathrm{Ba}\end{array}$ & $\begin{array}{l}2.7 \times 10^{-2} \pm \\
0.1 \times 10^{-2} \mathrm{Ba}\end{array}$ & $\begin{array}{l}3.9 \times 10^{-2} \pm \\
0.3 \times 10^{-2} \mathrm{Bb}\end{array}$ & $\begin{array}{l}6.3 \times 10^{-2} \pm \\
0.6 \times 10^{-2} \mathrm{Ac}\end{array}$ & $\begin{array}{c}7.7 \times 10^{-2} \pm \\
0.6 \times 10^{-2} \mathrm{ABd}\end{array}$ \\
\hline & & $\mathrm{R}^{2}$ & 0.9840 & 0.9898 & 0.9832 & 0.9661 & 0.9762 \\
\hline & & $\mathrm{t}_{90}$ (days) & 6.20 & 3.90 & 2.70 & 1.67 & 1.37 \\
\hline & \multirow[t]{3}{*}{70} & $\mathrm{k}_{\mathrm{obs}}\left(\mathrm{day}^{-1}\right)$ & $\begin{array}{l}4.6 \times 10^{-2} \pm \\
0.5 \times 10^{-2} \mathrm{Ca}\end{array}$ & $\begin{array}{l}7.2 \times 10^{-2} \pm \\
0.5 \times 10^{-2} \text { Cab }\end{array}$ & $\begin{array}{l}9.7 \times 10^{-2} \pm \\
0.6 \times 10^{-2} \mathrm{Cb}\end{array}$ & $\begin{array}{l}1.4 \times 10^{-1} \pm \\
0.1 \times 10^{-1} \mathrm{Bc}\end{array}$ & $\begin{array}{l}1.9 \times 10^{-1} \pm \\
0.2 \times 10^{-1} \mathrm{Bd}\end{array}$ \\
\hline & & $\mathrm{R}^{2}$ & 0.9577 & 0.9803 & 0.9837 & 0.9686 & 0.9611 \\
\hline & & $\mathrm{t}_{90}$ (days) & 2.29 & 1.46 & 1.09 & 0.753 & 0.555 \\
\hline & \multirow[t]{3}{*}{80} & $\mathrm{k}_{\mathrm{obs}}\left(\mathrm{day}^{-1}\right)$ & $\begin{array}{l}1.17 \times 10^{-1} \pm \\
0.6 \times 10^{-2} \mathrm{Da}\end{array}$ & $\begin{array}{l}1.4 \times 10^{-1} \pm \\
0.1 \times 10^{-1} \mathrm{Da}\end{array}$ & $\begin{array}{l}2.0 \times 10^{-1} \pm \\
0.2 \times 10^{-1} \mathrm{Da}\end{array}$ & $\begin{array}{l}4.6 \times 10^{-1} \pm \\
0.5 \times 10^{-1} \mathrm{Cb}\end{array}$ & $\begin{array}{l}6 \times 10^{-1} \pm \\
1 \times 10^{-1} \mathrm{Cb}\end{array}$ \\
\hline & & $\mathrm{R}^{2}$ & 0.9920 & 0.9764 & 0.9622 & 0.9819 & 0.9577 \\
\hline & & $\mathrm{t}_{90}$ (days) & 0.901 & 0.753 & 0.527 & 0.229 & 0.176 \\
\hline \multirow[t]{8}{*}{$\mathrm{TClHCl}$} & \multirow[t]{3}{*}{60} & $\mathrm{k}_{\mathrm{obs}}\left(\mathrm{day}^{-1}\right)$ & $\begin{array}{c}2.1 \times 10^{-3} \pm \\
0.2 \times 10^{-3} \mathrm{Abc}\end{array}$ & $\begin{array}{c}1.9 \times 10^{-3} \pm \\
0.2 \times 10^{-3} \text { Aabc }\end{array}$ & $\begin{array}{c}1.8 \times 10^{-3} \pm \\
0.3 \times 10^{-3} \text { Aabc }\end{array}$ & $\begin{array}{l}1.5 \times 10^{-3} \pm \\
0.1 \times 10^{-3} \mathrm{Aa}\end{array}$ & $\begin{array}{c}1.6 \times 10^{-3} \pm \\
0.2 \times 10^{-3} \text { Aab }\end{array}$ \\
\hline & & $\mathrm{R}^{2}$ & 0.9304 & 0.9260 & 0.7922 & 0.9384 & 0.9283 \\
\hline & & $\mathrm{t}_{90}$ (days) & 50.2 & 55.5 & 58.5 & 70.2 & 65.9 \\
\hline & \multirow[t]{2}{*}{70} & $\mathrm{k}_{\mathrm{obs}}\left(\mathrm{day}^{-1}\right)$ & $\begin{array}{l}1.7 \times 10^{-2} \pm \\
0.3 \times 10^{-2} \mathrm{Bc}\end{array}$ & $\begin{array}{c}7.3 \times 10^{-3} \pm \\
0.8 \times 10^{-3} \text { Bab }\end{array}$ & $\begin{array}{l}7 \times 10^{-3} \pm \\
1 \times 10^{-3} \mathrm{Bab}\end{array}$ & $\begin{array}{l}5.3 \times 10^{-3} \pm \\
0.7 \times 10^{-3} \mathrm{Ba}\end{array}$ & $\begin{array}{l}4.4 \times 10^{-3} \pm \\
0.4 \times 10^{-3} \mathrm{Ba}\end{array}$ \\
\hline & & $\begin{array}{c}\mathrm{R}^{2} \\
\mathrm{t}_{90} \text { (days) }\end{array}$ & $\begin{array}{c}0.8215 \\
6.20\end{array}$ & $\begin{array}{c}0.9283 \\
14.4\end{array}$ & $\begin{array}{c}0.8745 \\
15.1\end{array}$ & $\begin{array}{c}0.8823 \\
19.9\end{array}$ & $\begin{array}{c}0.9498 \\
23.9\end{array}$ \\
\hline & \multirow[t]{3}{*}{80} & $\mathrm{k}_{\mathrm{obs}}\left(\mathrm{day}^{-1}\right)$ & $\begin{array}{l}3.1 \times 10^{-2} \pm \\
0.1 \times 10^{-2} \mathrm{Cd}\end{array}$ & $\begin{array}{l}1.5 \times 10^{-2} \pm \\
0.1 \times 10^{-2} \mathrm{Ca}\end{array}$ & $\begin{array}{c}2.3 \times 10^{-2} \pm \\
0.3 \times 10^{-2} \mathrm{Cbc}\end{array}$ & $\begin{array}{c}2.4 \times 10^{-2} \pm \\
0.1 \times 10^{-2} \mathrm{Cbc}\end{array}$ & $\begin{array}{l}1.89 \times 10^{-2} \pm \\
0.09 \times 10^{-2} \mathrm{Cab}\end{array}$ \\
\hline & & $\mathrm{R}^{2}$ & 0.9873 & 0.9500 & 0.8928 & 0.9736 & 0.9857 \\
\hline & & $\mathrm{t}_{90}$ (days) & 3.40 & 7.02 & 4.58 & 4.39 & 5.57 \\
\hline
\end{tabular}

Table 3. Rate constants and t90 values for thiamine in solutions of TMN and TClHCl under all concentrations and temperatures studied. Uppercase superscript letters denote statistical significance within concentration for each vitamin salt form (down columns). Lowercase superscript letters denote statistical significance within temperature for each vitamin salt form (across rows).

${ }^{*}$ Error values indicated for $\mathrm{k}_{\text {obs }}$ values represent a 95\% confidence interval ${ }^{* *}$ t90 indicates time when $90 \%$ of the initial concentration of thiamine remains 
Table 4. Color parameters $\mathrm{L}$, a, and b values of selected $\mathrm{TMN}$ and $\mathrm{TClHCl}$ solutions at $80^{\circ} \mathrm{C}$. Superscript letters on $\mathrm{L}$, a, or b values denote statistical significance within their respective parameters.

\begin{tabular}{cccccc}
\hline $\begin{array}{c}\text { Vitamin } \\
\text { Form }\end{array}$ & Concentration & Time & $\begin{array}{c}\mathbf{L} \\
\mathbf{( 0 - 1 0 0 \% , ~ b l a c k -} \\
\text { white) }\end{array}$ & $\begin{array}{c}\text { a } \\
\text { (negative=green, } \\
\text { positive=red) }\end{array}$ & $\begin{array}{c}\text { b } \\
\text { (negative=blue, } \\
\text { positive=yellow) }\end{array}$ \\
\hline TMN & $27 \mathrm{mg} / \mathrm{mL}$ & 0 days & $80.0 \pm 0.7 \%^{\mathrm{AB}}$ & $-7.2 \pm 0.4^{\mathrm{E}}$ & $6.2 \pm 0.6^{\mathrm{D}}$ \\
& & 7 days & $82 \pm 2 \%^{\mathrm{A}}$ & $-11.6 \pm 0.4^{\mathrm{G}}$ & $15.8 \pm 0.2^{\mathrm{B}}$ \\
\hline TCIHCl & $27 \mathrm{mg} / \mathrm{mL}$ & 0 days & $77 \pm 1 \%^{\mathrm{BC}}$ & $-5.3 \pm 0.6^{\mathrm{D}}$ & $2.8 \pm 0.3^{\mathrm{F}}$ \\
& & 31 days & $16 \pm 1 \%^{\mathrm{E}}$ & $2.9 \pm 0.6^{\mathrm{B}}$ & $2.7 \pm 0.4^{\mathrm{F}}$ \\
\cline { 2 - 6 } & $100 \mathrm{mg} / \mathrm{mL}$ & 0 days & $77 \pm 2 \%^{\mathrm{BC}}$ & $-5.8 \pm 0.3^{\mathrm{DE}}$ & $3.1 \pm 0.1^{\mathrm{F}}$ \\
& & 31 days & $15 \pm 3 \%^{\mathrm{E}}$ & $-2 \pm 1^{\mathrm{C}}$ & $0 \pm 1^{\mathrm{G}}$ \\
\cline { 2 - 6 } & $500 \mathrm{mg} / \mathrm{mL}$ & 0 days & $76 \pm 1 \%^{\mathrm{C}}$ & $-6.8 \pm 0.3^{\mathrm{DE}}$ & $4.8 \pm 0.4^{\mathrm{E}}$ \\
& & 5 hours & $80.7 \pm 0.6 \%^{\mathrm{A}}$ & $-9.3 \pm 0.7^{\mathrm{F}}$ & $10.4 \pm 0.9^{\mathrm{C}}$ \\
& & 31 days & $40 \pm 2 \%^{\mathrm{D}}$ & $38 \pm 2^{\mathrm{A}}$ & $35.7 \pm 0.7^{\mathrm{A}}$ \\
\hline
\end{tabular}


Table 5. Calculated activation energies of $\mathrm{TMN}$ and $\mathrm{TClHCl}$ as a function of temperature.

\begin{tabular}{cccc}
\hline $\begin{array}{c}\text { Vitamin Salt } \\
\text { Form }\end{array}$ & $\begin{array}{c}\text { Concentration } \\
(\mathbf{m g} / \mathbf{m L} \mathbf{)}\end{array}$ & $\mathbf{E}_{\mathbf{A}} \mathbf{( \mathbf { k c a l } / \mathbf { m o l } )}$ & $\mathbf{E}_{\mathbf{A}} \mathbf{( \mathbf { k J } / \mathbf { m o l } )}$ \\
\hline TMN & 1 & 22 & 94 \\
& 5 & 21 & 88 \\
& 10 & 21 & 88 \\
& 20 & 25 & 105 \\
& 27 & 25 & 103 \\
\hline TClHCl & 1 & 32 & 133 \\
& 5 & 24 & 100 \\
& 10 & 30 & 124 \\
& 20 & 32 & 136 \\
& 27 & 29 & 120 \\
& 100 & 31 & 131 \\
& 300 & 32 & 135 \\
& 500 & 21 & 90 \\
\hline
\end{tabular}




\section{Figure Captions}

Figure 1. Chemical structures of A) thiamine, B) thiamine mononitrate, and C) thiamine chloride hydrochloride.

Figure 2. Degradation profiles of thiamine in TMN solutions in varying concentrations (1-27 $\mathrm{mg} / \mathrm{mL}$ ) at $80^{\circ} \mathrm{C}$ over time.

Figure 3. First-order degradation regression lines of thiamine in $5 \mathrm{mg} / \mathrm{mL}$ TMN solutions at temperatures from $25^{\circ} \mathrm{C}$ to $80^{\circ} \mathrm{C}$.

Figure 4. Arrhenius plots used to calculate temperature-dependent activation energy for TMN solutions $(1-27 \mathrm{mg} / \mathrm{mL})$ at temperatures from $25^{\circ} \mathrm{C}$ to $80^{\circ} \mathrm{C}$.

Figure 5. Degradation profiles of thiamine chloride in $\mathrm{TClHCl}$ solutions at varying concentrations $(1-500 \mathrm{mg} / \mathrm{mL})$ at $80^{\circ} \mathrm{C}$ over time.

Figure 6. First-order degradation regression lines of thiamine chloride in $1 \mathrm{mg} / \mathrm{mL} \mathrm{TClHCl}$ solutions at temperatures from $60^{\circ} \mathrm{C}$ to $80^{\circ} \mathrm{C}$.

Figure 7. Arrhenius plots used to calculate temperature-dependent activation energy for TClHCl solutions $(1-500 \mathrm{mg} / \mathrm{mL})$ at temperatures from $25^{\circ} \mathrm{C}$ to $80^{\circ} \mathrm{C}$.

Figure 8. Comparison of chemical stability over time of $\mathrm{TMN}$ and $\mathrm{TClHCl}$ in multiple concentrations of solution at A) $25^{\circ} \mathrm{C}$, B) $40^{\circ} \mathrm{C}$, C) $60^{\circ} \mathrm{C}$, D) $70^{\circ} \mathrm{C}$, and E) $80^{\circ} \mathrm{C}$ :

- $\mathrm{TMN} 1 \mathrm{mg} / \mathrm{mL}$ - $\mathrm{TMN} 5 \mathrm{mg} / \mathrm{mL}$ - TMN $10 \mathrm{mg} / \mathrm{mL} \quad \square \mathrm{TMN} 20 \mathrm{mg} / \mathrm{mL} \quad \Delta \mathrm{TMN} 27 \mathrm{mg} / \mathrm{mL}$

- $\mathrm{TClHCl} 1 \mathrm{mg} / \mathrm{mL} \quad \circ \mathrm{TClHCl} 5 \mathrm{mg} / \mathrm{mL} \quad \square \mathrm{TClHCl} 10 \mathrm{mg} / \mathrm{mL} \quad \square \mathrm{TClHCl} 20 \mathrm{mg} / \mathrm{mL} \quad \Delta \mathrm{TClHCl} 27 \mathrm{mg} / \mathrm{mL}$

$\Delta \mathrm{TClHCl} 100 \mathrm{mg} / \mathrm{mL} \bullet \mathrm{TClHCl} 300 \mathrm{mg} / \mathrm{mL} \diamond \mathrm{TClHCl} 500 \mathrm{mg} / \mathrm{mL}$

Figure 9. Speciation plot of thiamine as a function of $\mathrm{pH}$ prepared using only the $\mathrm{pK}_{\mathrm{a} 1}$ of thiamine (4.8) for the N1 nitrogen on the pyrimidine ring. Shaded areas indicate $\mathrm{pH}$ ranges of TClHCl and TMN samples, respectively.

Figure 10. pH change with temperature of pure water (Clark, 2017), TMN, and TClHCl for all concentrations studied. 
Figure 1

A)<smiles>Cc1ncc(C[n+]2csc(CCO)c2C)c(N)n1</smiles>

B)<smiles>Cc1ncc(C[n+]2csc(CCO)c2C)c(N)n1</smiles>

C)<smiles>Cc1nc(N)c(C[n+]2csc(CCO)c2C)c[nH+]1</smiles> 
Figure 2

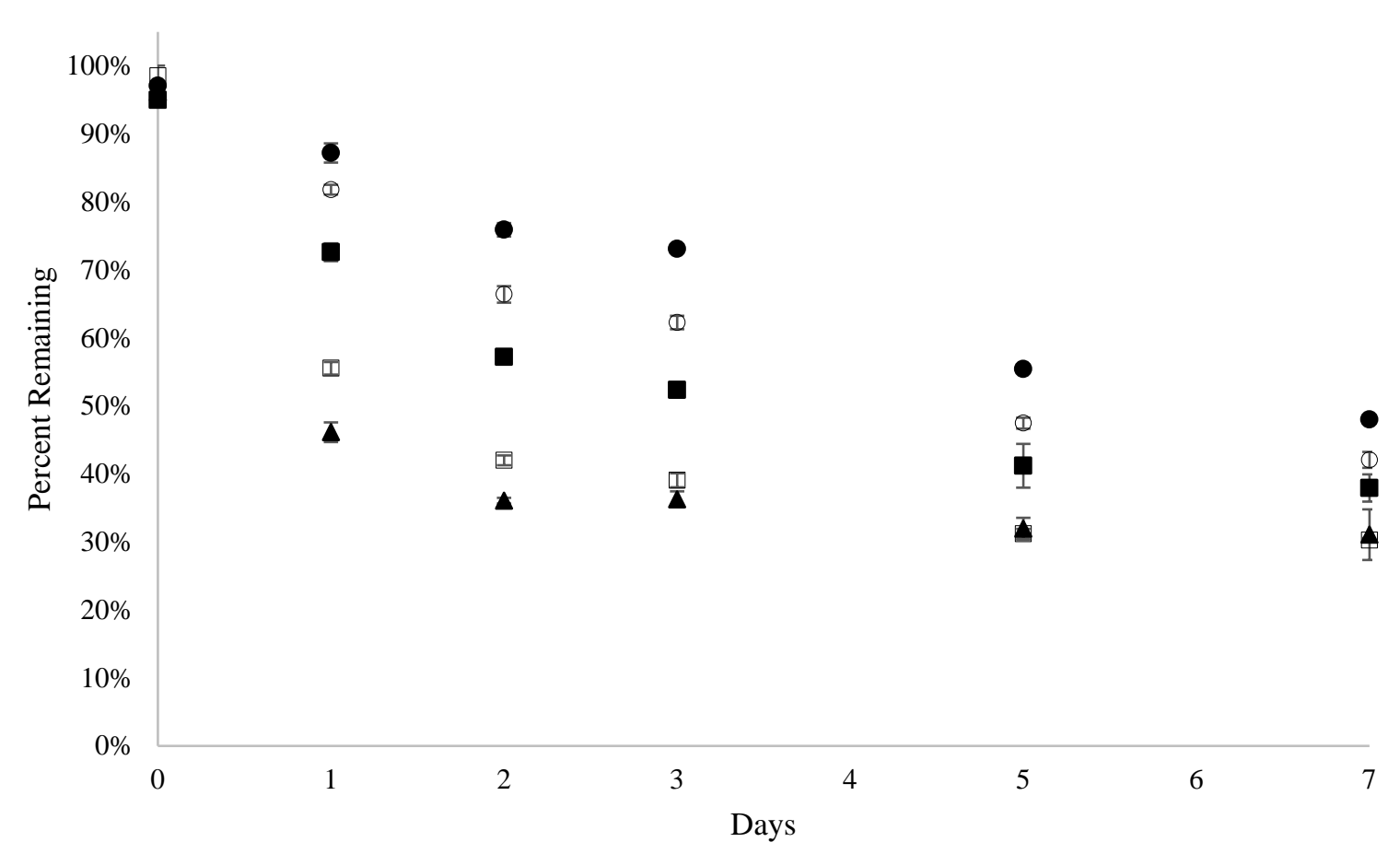

- TMN $1 \mathrm{mg} / \mathrm{mL} 80^{\circ} \mathrm{C} \quad \mathrm{OTMN} 5 \mathrm{mg} / \mathrm{mL} 80^{\circ} \mathrm{C}$-TMN $10 \mathrm{mg} / \mathrm{mL} 80^{\circ} \mathrm{C}$

$\square$ TMN $20 \mathrm{mg} / \mathrm{mL} 80^{\circ} \mathrm{C} \Delta \mathrm{TMN} 27 \mathrm{mg} / \mathrm{mL} 80^{\circ} \mathrm{C}$ 
Figure 3

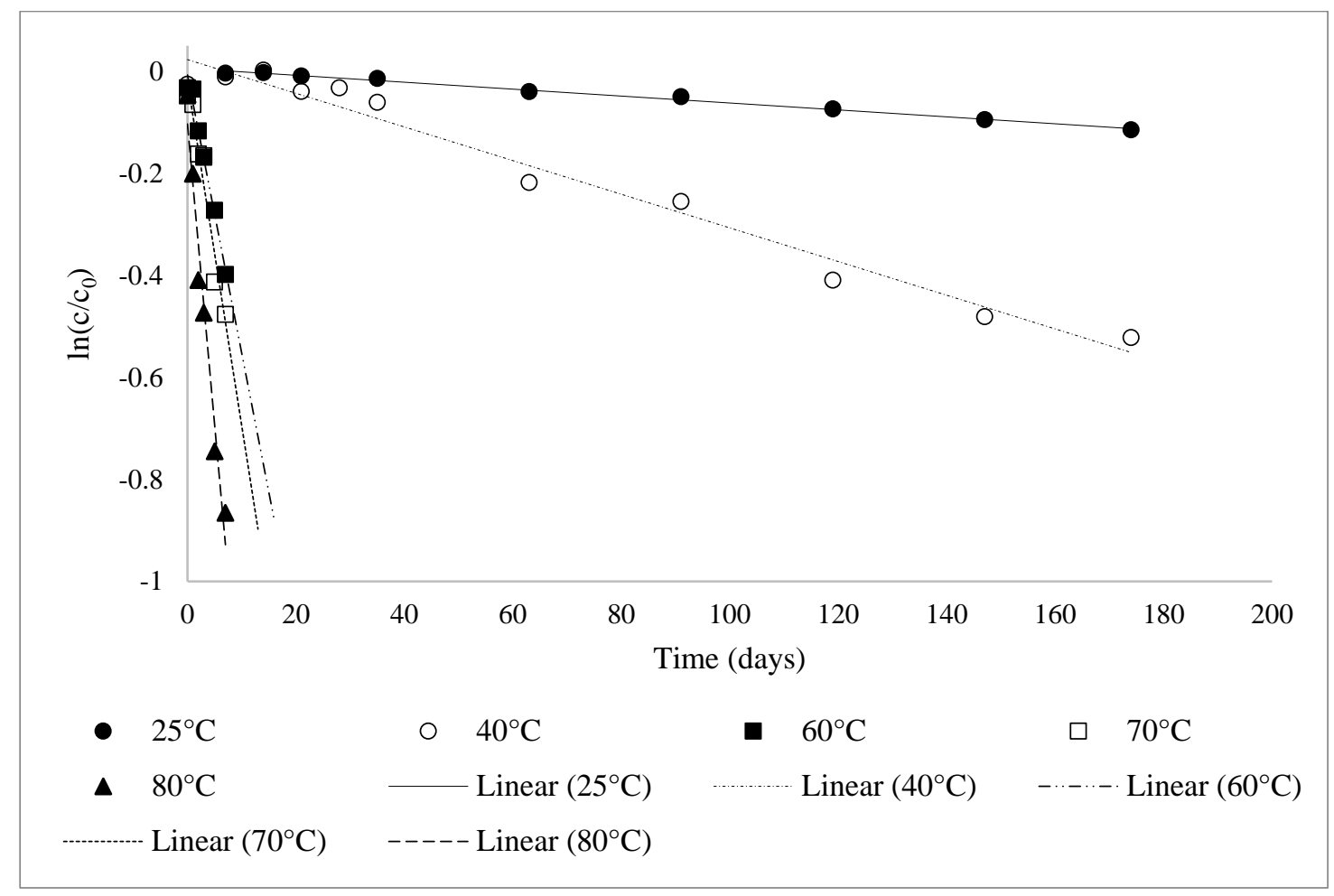




\section{Figure 4}

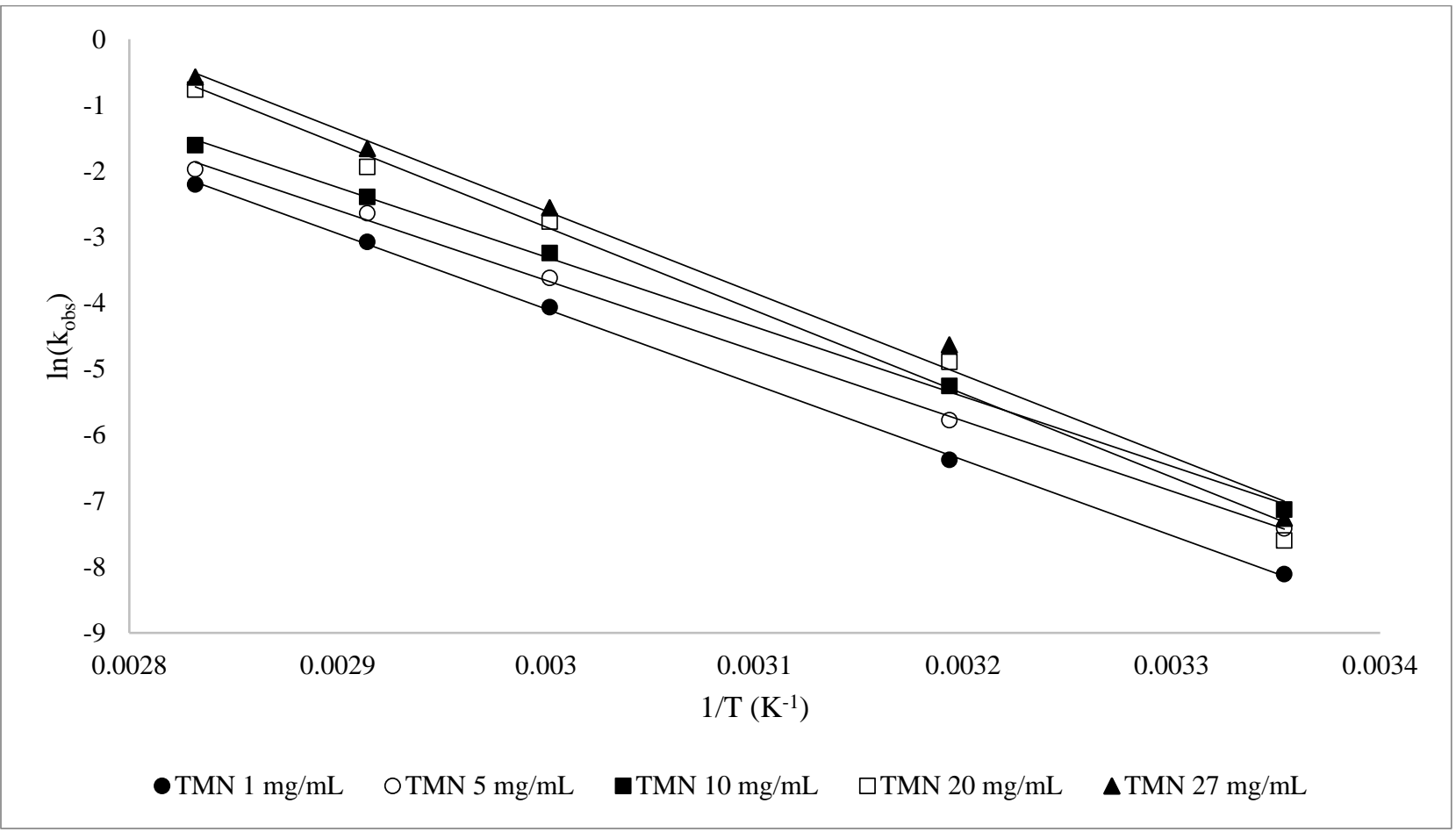


Figure 5

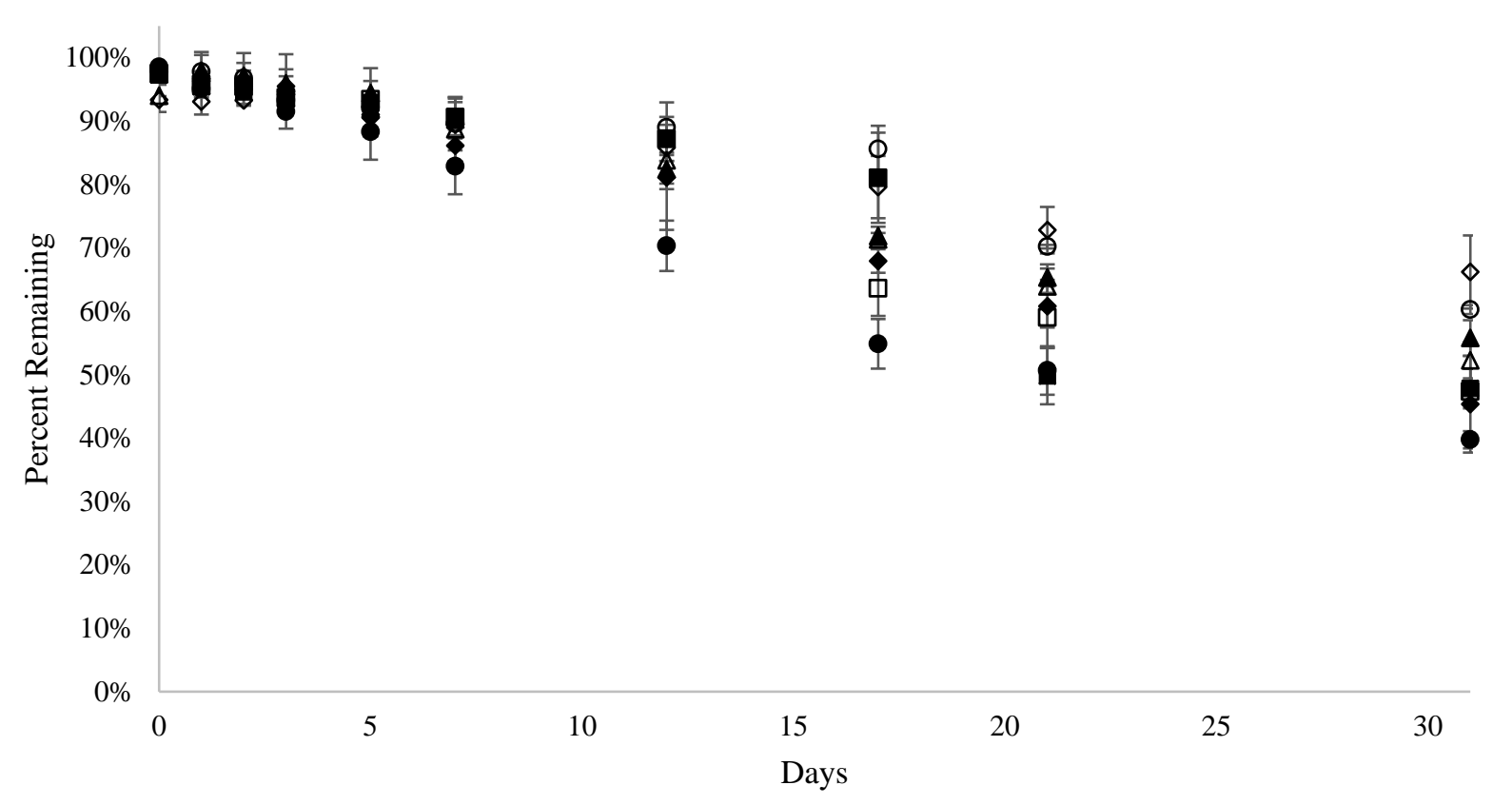

- TClHCl $1 \mathrm{mg} / \mathrm{mL} 80^{\circ} \mathrm{C} \quad$ OTClHCl $5 \mathrm{mg} / \mathrm{mL} 80^{\circ} \mathrm{C} \quad \mathbf{T C l H C l} 10 \mathrm{mg} / \mathrm{mL} 80^{\circ} \mathrm{C} \quad$ 口TClHCl $20 \mathrm{mg} / \mathrm{mL} 80^{\circ} \mathrm{C}$ $\Delta \mathrm{TClHCl} 27 \mathrm{mg} / \mathrm{mL} 80^{\circ} \mathrm{C} \quad \Delta \mathrm{TClHCl} 100 \mathrm{mg} / \mathrm{mL} 80^{\circ} \mathrm{C} \bullet \mathrm{TClHCl} 300 \mathrm{mg} / \mathrm{mL} 80^{\circ} \mathrm{C} \diamond \mathrm{TClHCl} 500 \mathrm{mg} / \mathrm{mL} 80^{\circ} \mathrm{C}$ 
Figure 6

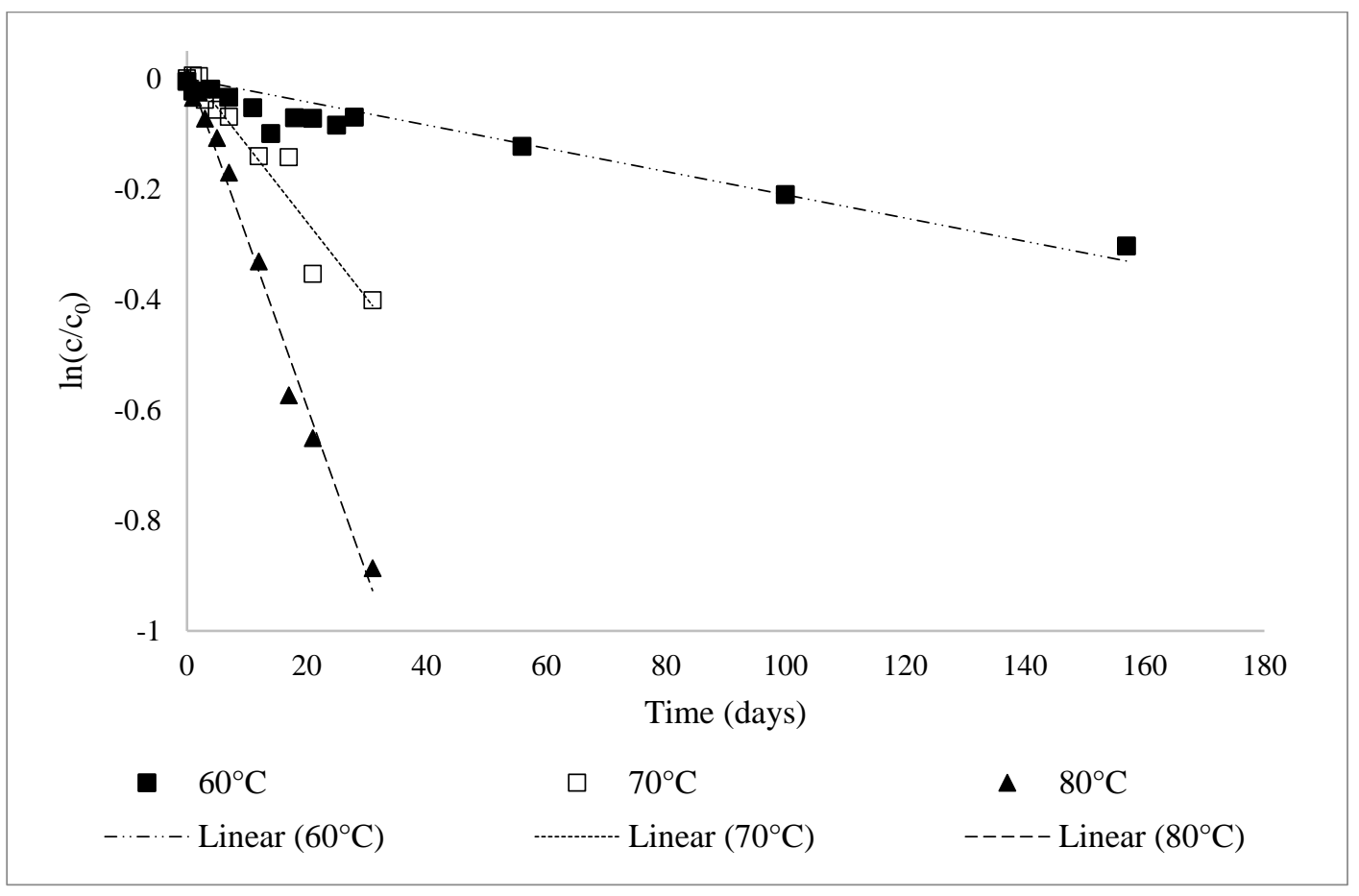




\section{Figure 7}

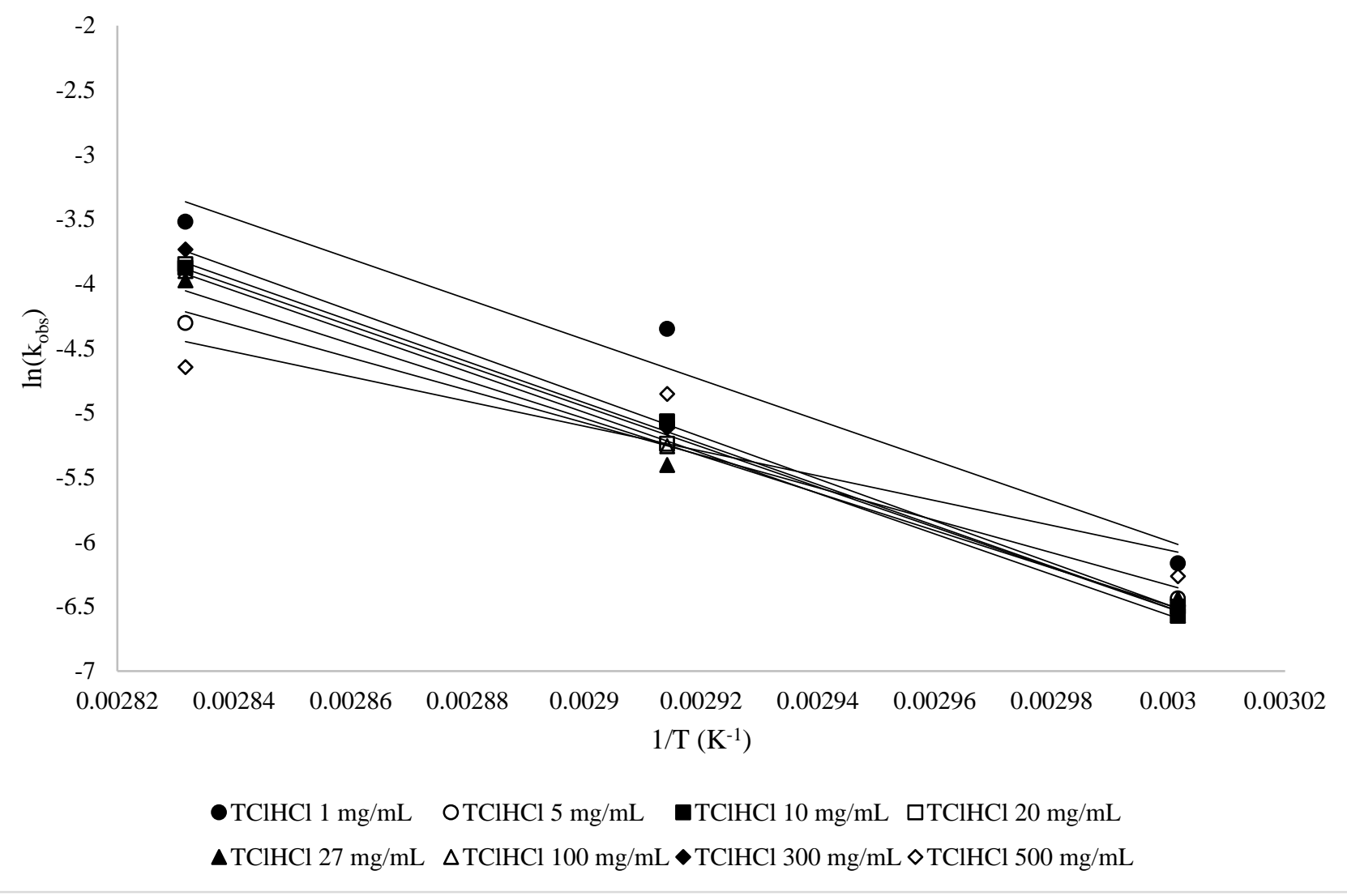


Figure 8

A)

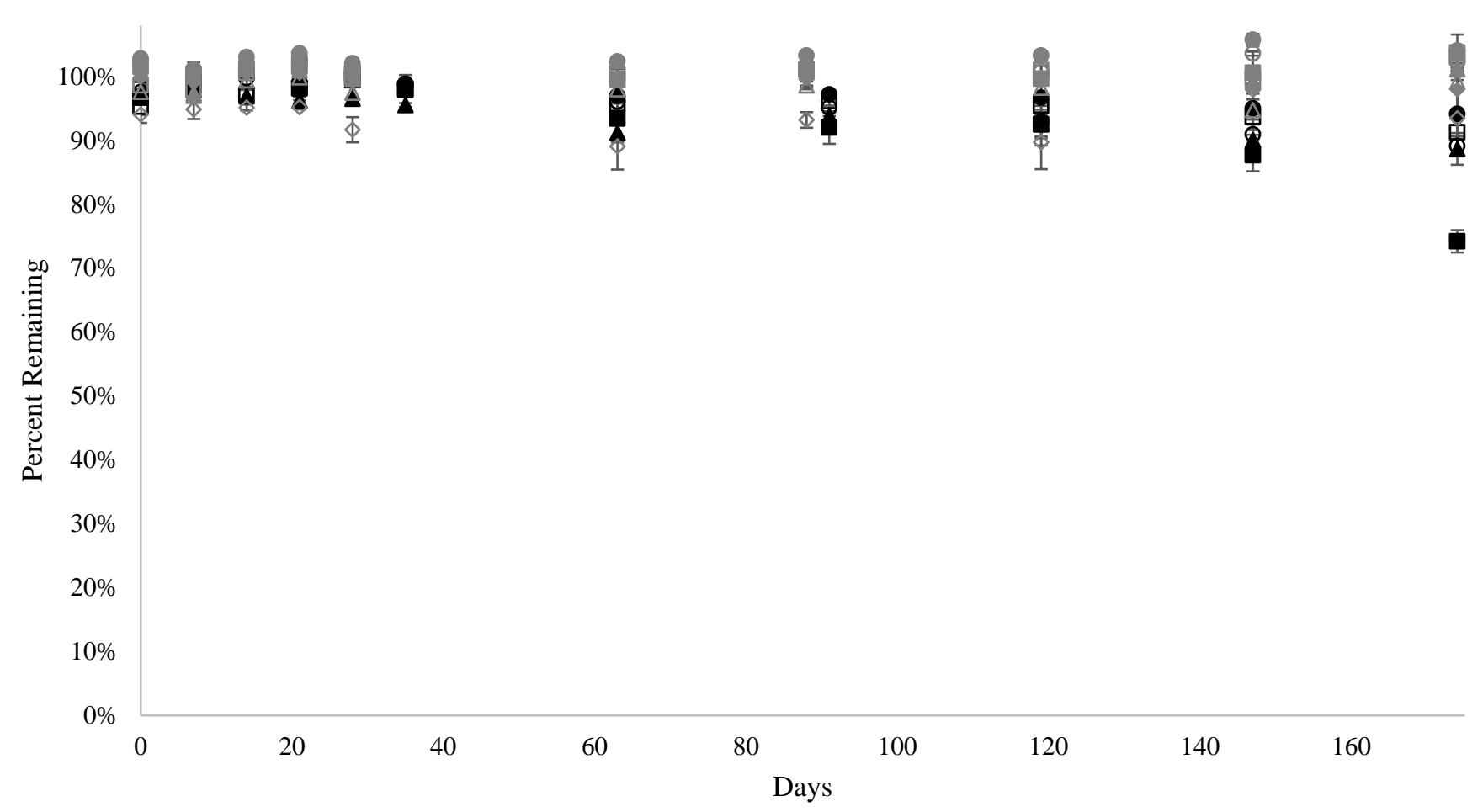

B)

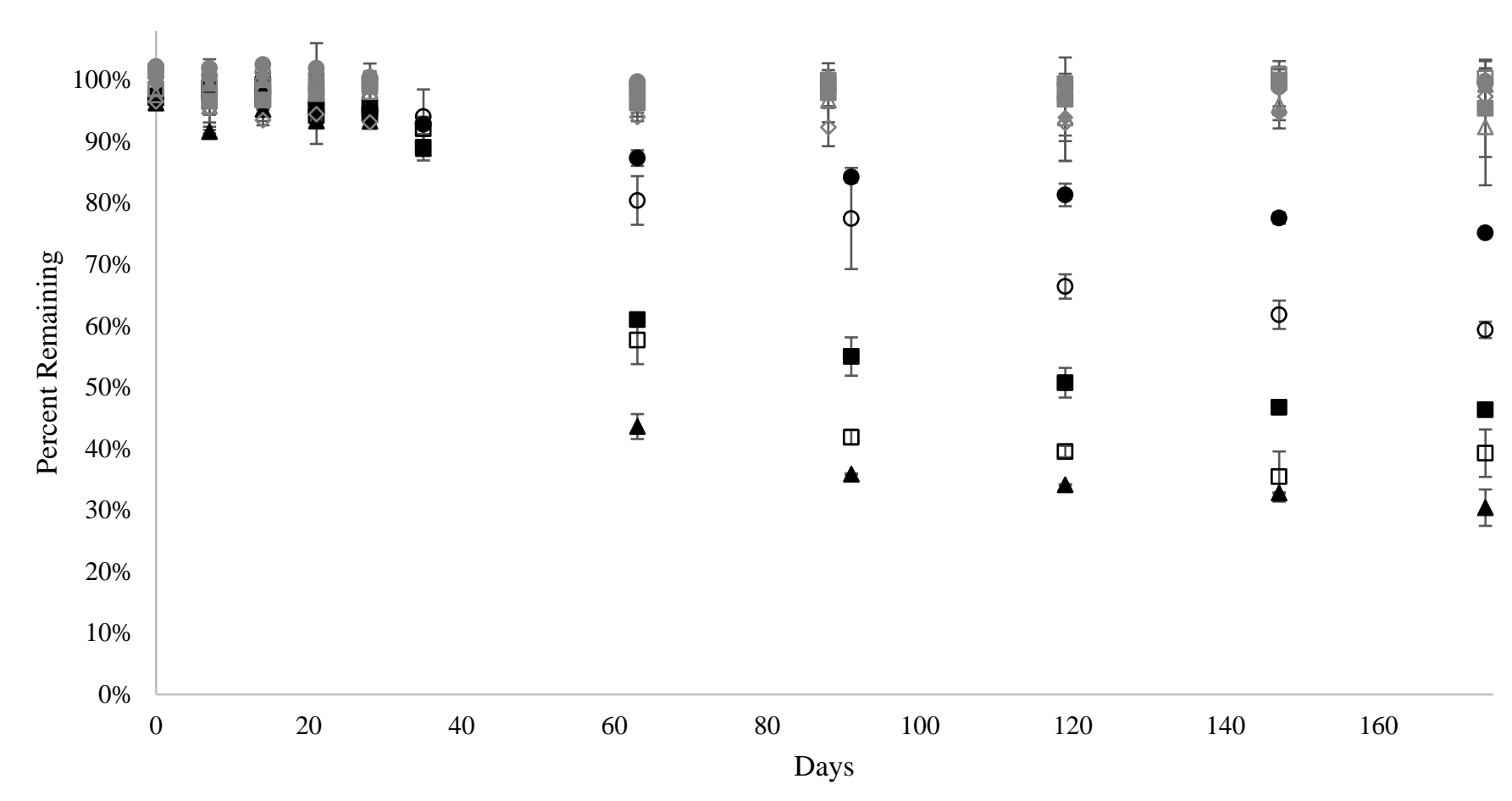


C)

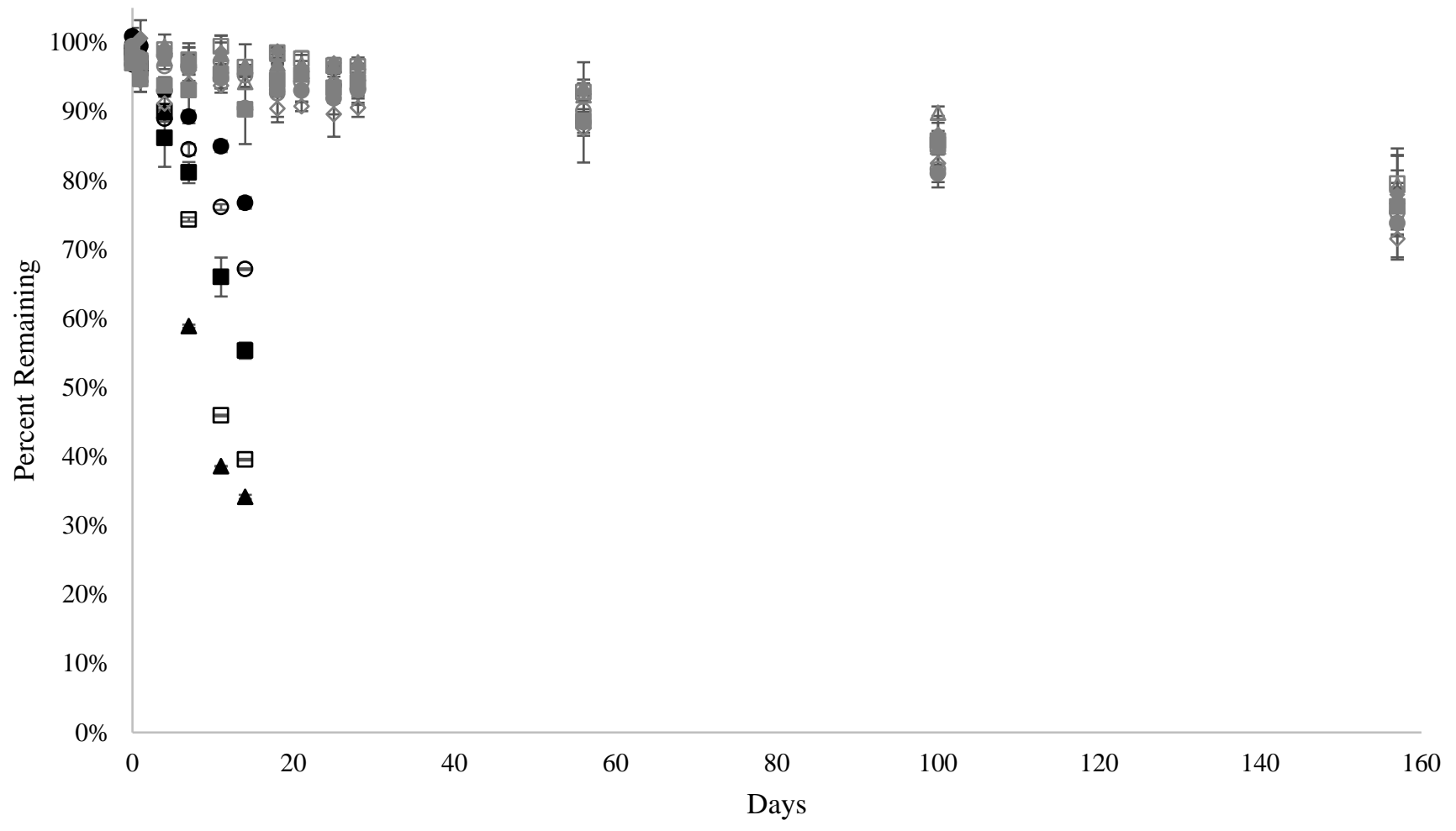

D)

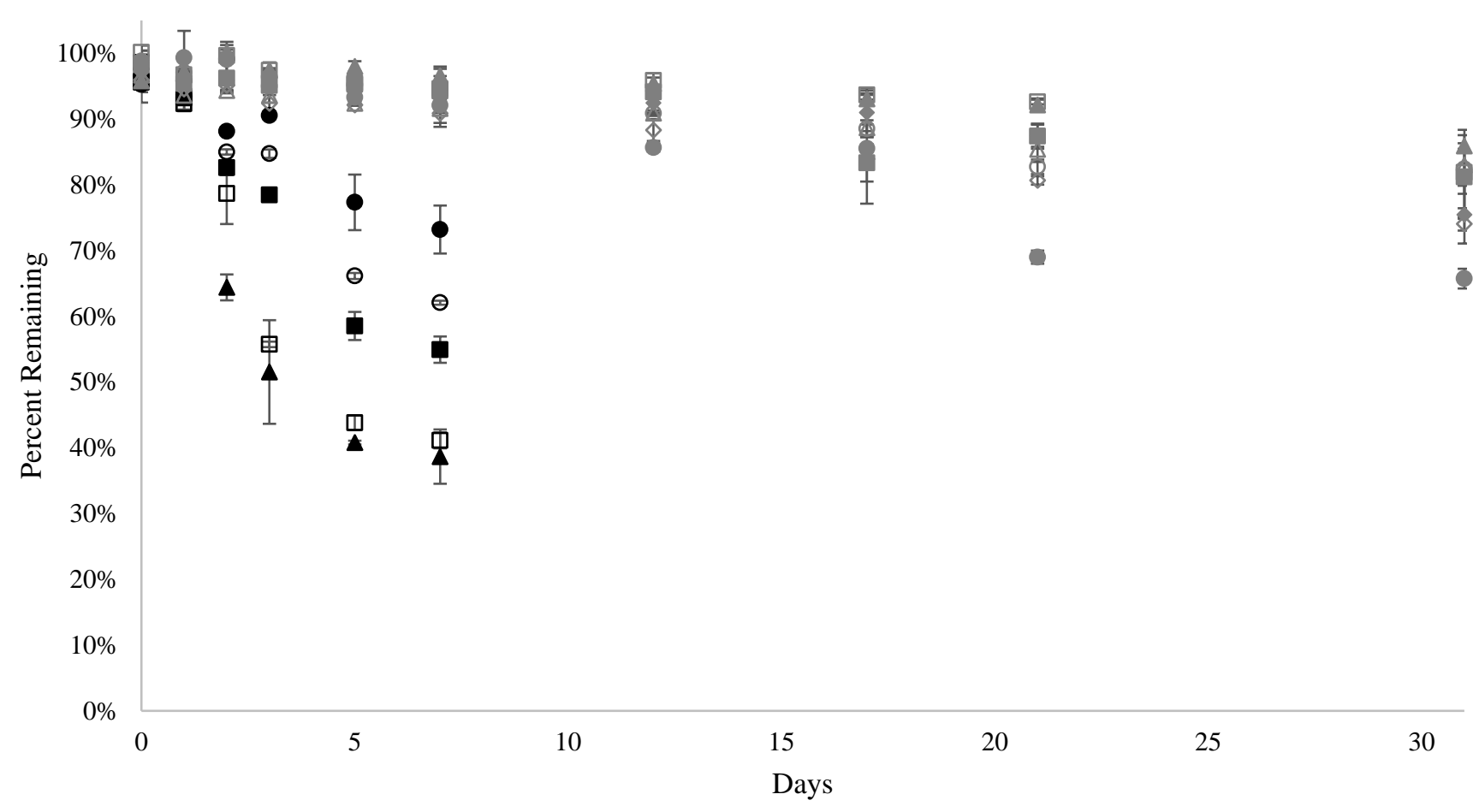


E)

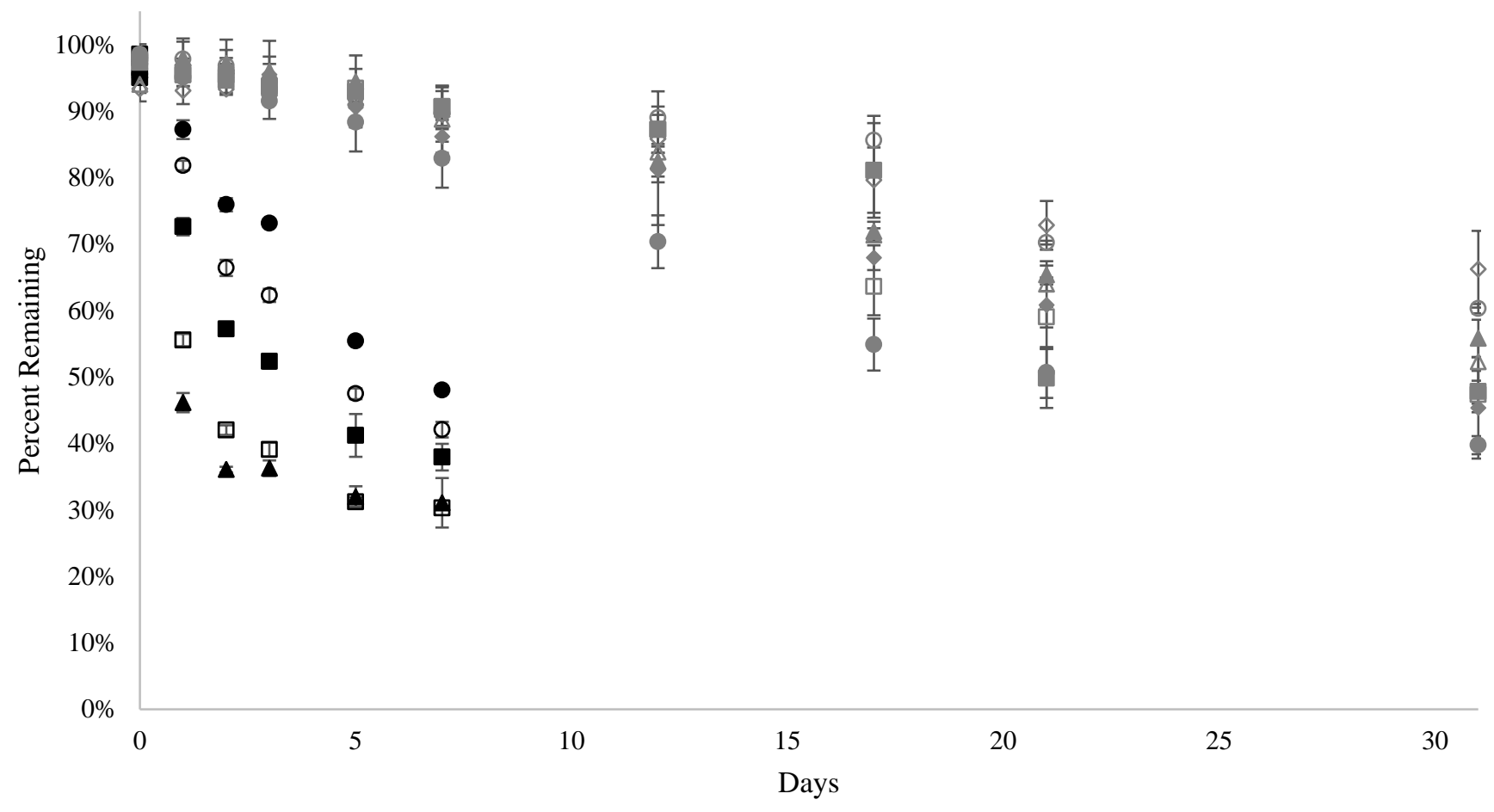


Figure 9

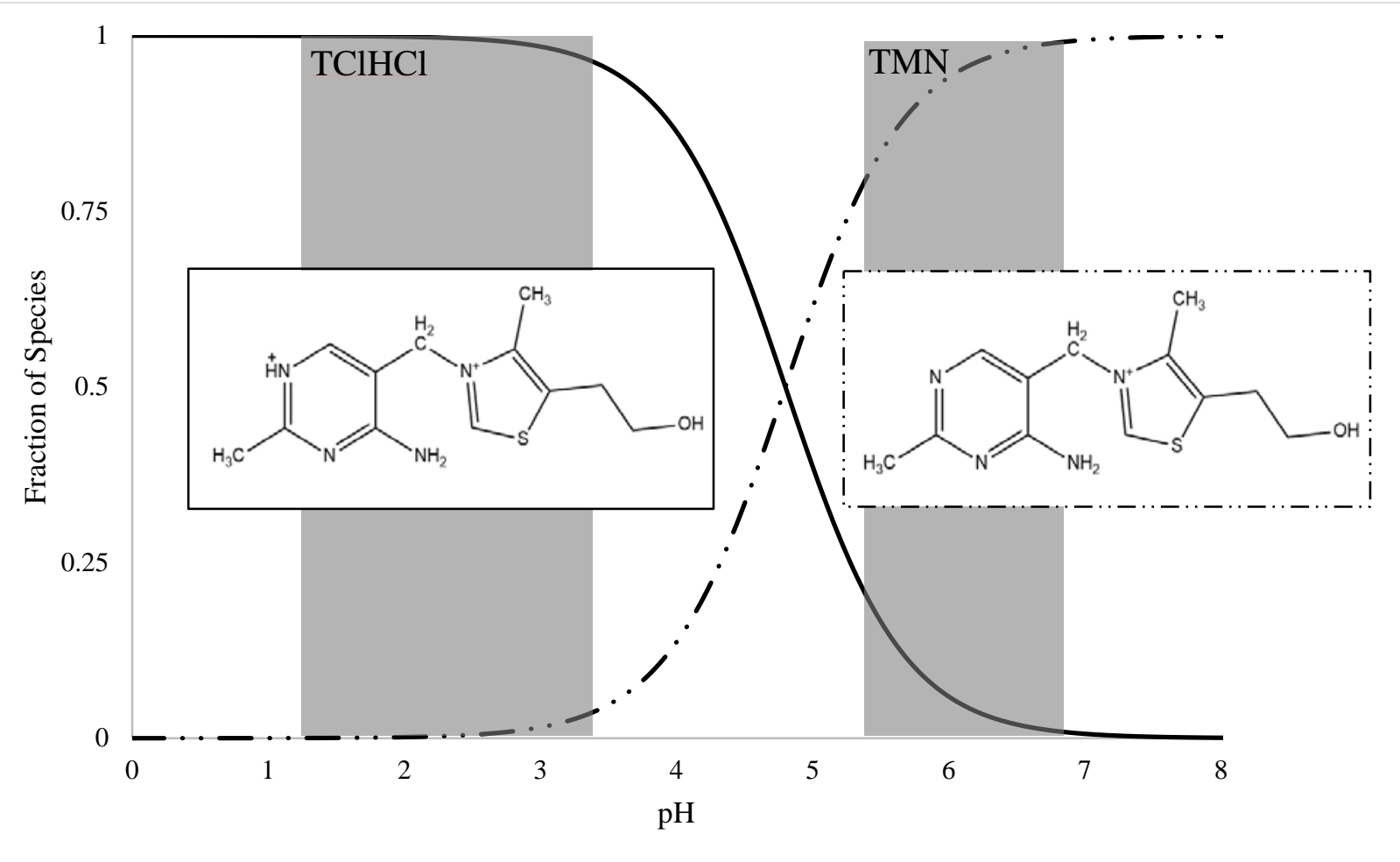




\section{Figure 10}

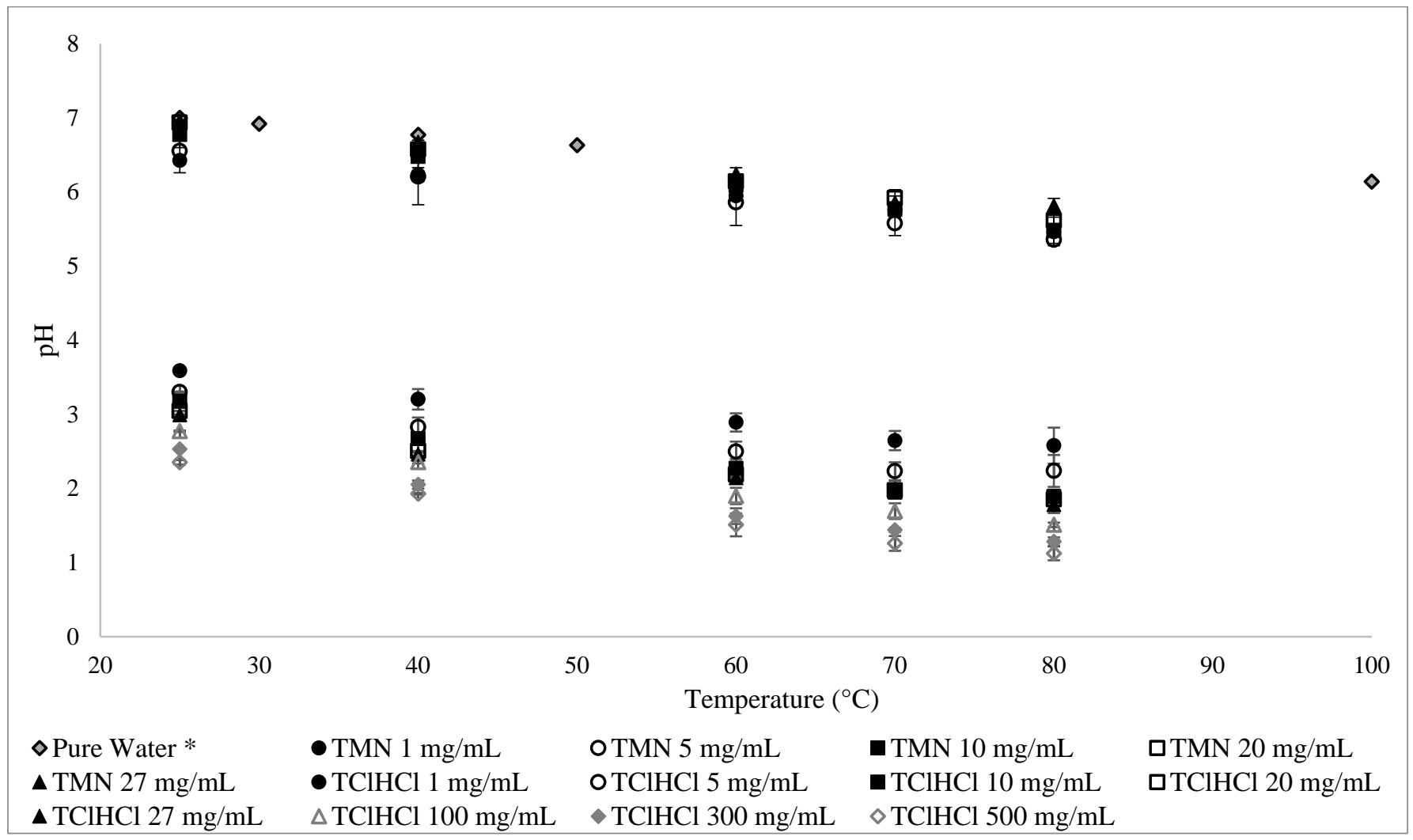

